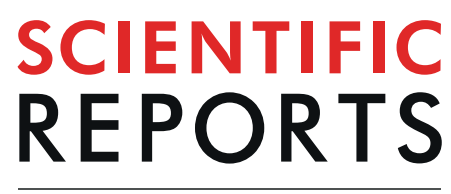

natureresearch

\title{
Cell surface processing of the P1 adhesin of Mycoplasma pneumoniae identifies novel domains that bind host molecules
}

\author{
Michael Widjaja ${ }^{1}$, lain James Berry ${ }^{1}$, Veronica Maria Jarocki ${ }^{1}$, Matthew Paul Padula ${ }^{3}$, \\ Roger Dumke ${ }^{2,4}$ \& Steven Philip Djordjevic ${ }^{1,3,4^{*}}$
}

\begin{abstract}
Mycoplasma pneumoniae is a genome reduced pathogen and causative agent of community acquired pneumonia. The major cellular adhesin, $\mathrm{P} 1$, localises to the tip of the attachment organelle forming a complex with P40 and P90, two cleavage fragments derived by processing Mpn142, and other molecules with adhesive and mobility functions. LC-MS/MS analysis of M. pneumoniae M129 proteins derived from whole cell lysates and eluents from affinity matrices coupled with chemically diverse host molecules identified 22 proteoforms of $\mathrm{P} 1$. Terminomics was used to characterise 17 cleavage events many of which were independently verified by the identification of semitryptic peptides in our proteome studies and by immunoblotting. One cleavage event released ${ }^{1597}$ TSAAKPGAPRPPVPPKPGAPKPPVOPPKKPA ${ }^{1627}$ from the $\mathrm{C}$-terminus of $\mathrm{P} 1$ and this peptide was shown to bind to a range of host molecules. A smaller synthetic peptide comprising the $\mathrm{C}$-terminal 15 amino acids, ${ }^{1613}$ PGAPKPPVOPPKKPA ${ }^{1627}$, selectively bound cytoskeletal intermediate filament proteins cytokeratin 7 , cytokeratin 8 , cytokeratin 18 , and vimentin from a native $A 549$ cell lysate. Collectively, our data suggests that ectodomain shedding occurs on the surface of $M$. pneumoniae where it may alter the functional diversity of $\mathrm{P} 1, \mathrm{Mpn} 142$ and other surface proteins such as elongation factor Tu via a mechanism similar to that described in Mycoplasma hyopneumoniae.
\end{abstract}

The attachment organelle is a structurally and functionally sophisticated component of the M. pneumoniae cell that is responsible for the assembly of proteins essential for motility and adherence ${ }^{1-8}$. An extensive list of host molecules including fibronectin ${ }^{9-13}$, fibrinogen ${ }^{10-14}$, plasminogen ${ }^{11-13,15-17}$, lactoferrin ${ }^{10-12}$, laminin ${ }^{10-12}$, and vitronectin ${ }^{10-13}$ interact with surface accessible adhesins in M. pneumoniae. Other less well-defined host molecules include sialylated molecules ${ }^{18}$, oligosaccharides ${ }^{19}$, glycolipids $^{20}$, and glycoproteins ${ }^{21}$.

The gene mpn141 encoding the major adhesin P1 is located in the same operon along with mpn140 and $m p n 142$ and these three genes constitute a polycistronic transcriptional unit ${ }^{22,23} . m p n 140$ encodes for a $28 \mathrm{kDa}$ putative phosphoesterase ${ }^{24}$ and while it has been shown to degrade nanoRNA and dephosphorylate $3^{\prime}$-phosphoadenosine $5^{\prime}$-phosphate to AMP ${ }^{25}$, no role in adherence has been assigned for this protein. mpn142 generates a $130 \mathrm{kDa}$ product (Mpn142) that is cleaved into two fragments of $40 \mathrm{kDa}(\mathrm{P} 40)$ and $90 \mathrm{kDa}(\mathrm{P} 90)$ immediately after or concurrent with translation ${ }^{26,27}$. The cleavage event in Mpn142, first described over 25 years ago, was the first in what is now known to be a highly processed molecule on the surface of $M$. pneumoniae ${ }^{28}$. P1 is a remarkably versatile molecule and the subject of numerous studies over the past 30 years. The only cleavage event that has been accurately assigned to $\mathrm{P} 1$ is the removal of the $\mathrm{N}$-terminal 59 amino acids as a leader peptide $^{29}$. Molecular cross-linking and immunogold-labelling studies indicated that P1 forms a complex with P30, $\mathrm{P} 40$, and $\mathrm{P} 90^{30,31}$ that colocalise to the tip of the attachment organelle to act in concert to effect different functions $^{5,6,23,32}$. Cross-linking studies with paraformaldehyde identified P1 complexes containing Mpn309 (P65), Mpn272 (DnaK), C-terminal truncated forms of DnaK and P1, pyruvate dehydrogenase $\alpha$ subunit (Pdh-A), and

\footnotetext{
${ }^{1}$ The ithree institute, University of Technology Sydney, PO Box 123, Broadway, NSW, 2007, Australia. ${ }^{2}$ Technische Universität Dresden, Medizinische Fakultät Carl Gustav Carus, Institut für Medizinische Mikrobiologie und Hygiene, Fetscherstrasse 74, 01307, Dresden, Germany. ${ }^{3}$ Proteomics Core Facility and School of Life Sciences, University of Technology Sydney, PO Box 123, Broadway, NSW, 2007, Australia. ${ }^{4}$ These authors contributed equally: Roger Dumke and Steven Philip Djordjevic. *email: Steven.Djordjevic@uts.edu.au
} 
high molecular weight proteins 1 (HMW1) and 3 (HMW3) ${ }^{33}$. Anti-P1 antibodies reduce adherence of $M$. pneumoniae to abiotic and host cell surfaces ${ }^{3,34-38}$ and M. pneumoniae P1 mutants are also unable to adhere ${ }^{35,36,39-41}$. For P1 to translocate to the surface, localise correctly within the attachment organelle and to maintain stability, interactions with accessory proteins P40, P90, HMW1, and TopJ are required ${ }^{2,42-46}$. C-terminal regions of P1 have featured in various recombinant vaccines that seek to control infections caused by M. pneumoniae.

The P1 adhesin is highly immunogenic and is often detected by sera from M. pneumoniae-infected patients $^{36,47,48}$. Several studies have shown that the carboxyl half of P1 is highly immunogenic and crucial for its function as an adhesin ${ }^{37,49-55}$. To identify regions within P1 that are recognised by the host humoral immune response, Schurwanz et al. generated 15 recombinant fragments spanning the P1 molecule and exposed them to the serum of patients with M. pneumoniae infections ${ }^{55}$. Three recombinant fragments within P1, one in the $\mathrm{N}$-terminus and two spanning C-terminal regions, were strongly immunoreactive with sera from greater than $90 \%$ of the patients ${ }^{55}$. Guinea pig antibodies generated to one of the C-terminal regions significantly reduced binding of M. pneumoniae to HBEC (primary bronchial epithelial), MRC-5 (fetal lung fibroblasts), and HeLa (cervical carcinoma) cell lines ${ }^{55}$. These data informed the creation of a chimeric recombinant protein which included this carboxyl region of P1 and a region in the P30 adhesin. Antibodies raised against this chimeric protein reduced M. pneumoniae adherence to human bronchial epithelial cells by more than $95 \%{ }^{55}$, and also successfully reduced $M$. pneumoniae colonisation in animal models ${ }^{56}$.

Here we sought to determine if $\mathrm{P} 1$ is processed on the surface of $M$. pneumoniae. Tryptic peptides that mapped to different regions within P1 were frequently encountered when characterising size-fractionated eluents generated during affinity chromatography using different host molecules as bait. These peptides were mapped to the $\mathrm{P} 1$ molecule providing insight into the complex processing events that target this molecule. Precise cleavage sites were determined using an $\mathrm{N}$-terminome approach ${ }^{57}$ and by mapping semi-tryptic peptides identified from our proteome studies. Naturally occurring cleavage fragments of P1 were identified by LC-MS/MS analysis i) because they bound to affinity resins loaded with host proteins, ii) by mapping tryptic peptides derived from proteins spots from 2D-SDS PAGE, and iii) by immunoblotting studies using serum raised against fifteen different regions of $\mathrm{P} 1$. These independently acquired, but complementary datasets enabled a rigorous assessment of cleavage events in the P1 adhesin. Finally, microtitre binding assays and microscale thermophoresis showed that the C-terminus of P1 binds various host molecules.

\section{Methods and Materials}

Strains. M. pneumoniae (M129 strain, ATCC 29342) cells were cultured as described previously ${ }^{58}$. Cells were grown in modified Hayflick's medium in tissue culture flasks at $37^{\circ} \mathrm{C}$. Human lung carcinoma (A549, ATCC CCL-185) cells were cultured in RPMI 1640 medium (Invitrogen) supplemented with $10 \%$ heat inactivated fetal bovine serum. Cells were grown in tissue culture flasks at $37^{\circ} \mathrm{C}$ with $5 \% \mathrm{CO}_{2}$.

Cell preparation for one dimensional- and two dimensional-SDS polyacrylamide gel electrophoresis. M. pneumoniae cells were harvested as described previously ${ }^{59}$. In brief, cells were lysed with sonication in $7 \mathrm{M}$ urea, $2 \mathrm{M}$ thiourea, $40 \mathrm{mM}$ Tris- $\mathrm{HCl}$, and $1 \%(\mathrm{w} / \mathrm{v}) \mathrm{C} 7 \mathrm{BzO}$ detergent (Sigma) after washing with PBS. Proteins were reduced and alkylated with $5 \mathrm{mM}$ tributylphosphine and $20 \mathrm{mM}$ acrylamide monomers before precipitation with acetone. Protein was resuspended in $7 \mathrm{M}$ urea, $2 \mathrm{M}$ thiourea, and $1 \%(\mathrm{w} / \mathrm{v}) \mathrm{C} 7 \mathrm{BzO}$ for $1 \mathrm{D}$ - and 2D-SDS PAGE.

Gel electrophoresis was performed as described previously ${ }^{60,61}$. Approximately $80 \mu \mathrm{g}$ and $250 \mu \mathrm{g}$ of protein was used for 1D- and 2D-SDS PAGE, respectively. Gels were fixed and stained by either Flamingo fluorescent gel stain (Bio-Rad) or Coomassie Blue G-250 (Sigma).

In-gel trypsin digestion was performed as described previously ${ }^{62}$ for mass spectrometry analysis. Gel pieces were excised, destained, dehydrated, and then incubated with trypsin Gold MS grade (Promega) in $100 \mathrm{mM}$ $\mathrm{NH}_{4} \mathrm{HCO}_{3}$. Tryptic peptides were extracted by sonication and stored in $4^{\circ} \mathrm{C}$ until needed for mass spectrometry.

Liquid chromatography tandem mass spectrometry (LC-MS/MS) and data analysis. LC-MS/ MS was performed as described previously ${ }^{61}$. In brief, $5 \mu \mathrm{g}$ of peptides in $15 \mu \mathrm{l}$ was loaded into an Eksigent AS- 1 autosampler connected to a Tempo nanoLC system (Eksigent, Livermore, CA, USA) and washed onto a PicoFrit column $(75 \mu \mathrm{m} \times 150 \mathrm{~mm})$ packed with Magic C18AQ resin (Michrom Biosciences, CA). Peptides were eluted from the column into the source of a QSTAR Elite hybrid quadrupole-time-of-flight mass spectrometer (Sciex, Redwood, CA, USA).

Files generated from LC-MS/MS were searched against the MSPnr100 database ${ }^{63}$ with the following parameters: Fixed modifications: none; Variable modifications: propionamide, oxidized methionine, deamidation; Enzyme: semi-trypsin; Number of allowed missed cleavages: 3; Peptide mass tolerance: 100 ppm; MS/MS mass tolerance: $0.2 \mathrm{Da}$; and Charge state: $2+, 3+$, and $4+$. For samples collected from the 'Surface proteome analysis of M. pneumoniae (Biotinylation)' and 'Affinity chromatography host binding M. pneumoniae complexes (A549)' listed below, variable modifications also included NHS-LC-Biotin (K) and NHS-LC-Biotin (N-term). 'Affinity chromatography host binding M. pneumoniae complexes (A549)' was also searched against 'homo sapiens' entries in MSPnr100 to identify biotinylated surface A549 proteins.

Surface proteome analysis of M. pneumoniae. Biotinylation of the M. pneumoniae cells was performed as described previously ${ }^{28}$. The biotinylation reaction was allowed to proceed for 30 seconds on ice. Biotinylated surface proteins were confirmed with western blots using ExtrAvidin-HRP (Sigma).

Trypsin shaving of M. pneumoniae cells was carried out as described previously ${ }^{12}$. Shaving was for 5 minutes at $37^{\circ} \mathrm{C}$ and released peptides were trypsin digested a second time before analysis by LC-MS/MS. 
Affinity chromatography of host binding M. pneumoniae complexes. 'Bait' host proteins used for affinity chromatography include fibronectin (Code: 341635 ) and plasminogen (Code: 528175) from human plasma supplied by Merck Millipore. Bovine actin (Code: A3653) and fetuin (Code: F3004) was supplied by Sigma.

Affinity chromatography using host proteins bound to Avidin Agarose (Pierce) as 'Bait' was performed as described previously ${ }^{28}$. M. pneumoniae cells were lysed in $1 \%$ (w/v) C7BzO (Sigma-Aldrich) in PBS (pH 7.8) to obtain native complexes. The native complex cell lysate was incubated with host proteins bound to Avidin Agarose ('Bait'). This mixture was washed with PBS and host protein binding complexes ('Prey') were eluted 7M urea, $2 \mathrm{M}$ thiourea, $40 \mathrm{mM}$ Tris- $\mathrm{HCl}$, and $1 \%(\mathrm{w} / \mathrm{v}$ ) C7BzO. Elutions were separated by $1 \mathrm{D}-\mathrm{SDS}$ PAGE and proteins were identified by LC-MS/MS as described above.

Affinity chromatography using human lung carcinoma (A549) surface proteins as 'Bait' was performed as described previously ${ }^{28}$. A549 cells were biotinylated, lysed, and bound to Avidin Agarose ('Bait'). As above, this mixture was incubated with native $M$. pneumoniae complexes followed by washes and eluents to obtain a fraction of A549 binding complexes ('Prey').

Affinity chromatography using heparin HiTrap columns (GE Healthcare) was performed as described previously ${ }^{28}$. M. pneumoniae cells were lysed in $10 \mathrm{mM}$ sodium phosphate, $0.1 \%$ Triton TX-100 (pH 7.0) to obtain native complexes. Approximately $300 \mu \mathrm{g}$ of soluble complexes was loaded onto a HiTrap Heparin HP column (GE Healthcare). The column was washed with $10 \mathrm{mM}$ sodium phosphate ( $\mathrm{pH} 7.0)$ and heparin binding complexes were sequentially eluted in increasing concentrations of sodium chloride ( $\mathrm{pH}$ 7.0).

Dimethyl labelling of M. pneumoniae and LC-MS/MS analysis. Dimethyl labelling of M. pneumoniae proteins was carried out as described previously ${ }^{28,64} .1 \mathrm{mg}$ of $M$. pneumoniae protein was labelled in $40 \mathrm{mM}$ formaldehyde (Ultrapure grade, Polysciences), $20 \mathrm{mM}$ sodium cyanoborohydride, $100 \mathrm{mM}$ Hepes (pH 6.7) for 4 hours at $37^{\circ} \mathrm{C}$. The reaction was quenched with $100 \mathrm{mM}$ ammonium bicarbonate, precipitated in acetone:methanol $(8: 1)$, and digested with trypsin.

Peptides were analysed using both the Sciex 5600 and Thermo Scientific Q Exactive ${ }^{\mathrm{TM}}$ mass spectrometers. The methods, protocols, and parameters used have been described previously ${ }^{28}$.

Bioinformatic analysis of the P1 adhesin. Bioinformatic predictions and analysis was performed as described previously ${ }^{28}$. The bioinformatic tools used were: ProtParam ${ }^{65}$, TMpred ${ }^{66}$, PONDR ${ }^{\circledR}$ (VSL2 predictor $)^{67}$, and ScanProsite ${ }^{68}$. Predicted glycosaminoglycan binding motifs searched in ScanProsite included binding sites for heparin (X-[HRK]-[HRK]-X-[HRK]-X motif) ${ }^{69}$, heparin sulfate (X-[HRK]-X-[HRK]$[\mathrm{HRK}]-\mathrm{X})^{70}$, or clusters of basic amino acid residues (X-[HRK]-X $(0,2)-[\mathrm{HRK}]-\mathrm{X}(0,2)-[\mathrm{HRK}]-\mathrm{X}$ and $\mathrm{X}$-[HRK]-X(1,3)-[HRK]-X(1,3)-[HRK]-X).

Immunoblot of M. pneumoniae cell lysates using Anti-P1 serum. $60 \mu \mathrm{g}$ of M. pneumoniae cell lysate proteins were separated on 1D-SDS PAGE as described above. Proteins were transferred to PVDF (polyvinylidene fluoride) membranes using a semidry method ${ }^{71}$. Membranes were blocked with $5 \%(\mathrm{w} / \mathrm{v})$ skim milk powder in PBS, and $0.1 \%(\mathrm{v} / \mathrm{v})$ Tween 20 (PBS-Tween) for 1 hour at $25^{\circ} \mathrm{C}$. Membranes were cut in to individual lanes and then separately probed with guinea pig sera raised against different regions of the P1 adhesin (guinea pig sera was generated in a previous study $y^{55}$ ) for 1.5 hours at $25^{\circ} \mathrm{C}$ in PBS-Tween. Membranes were washed three times over 30 minutes before being probed a second time in peroxidase-conjugated anti-guinea pig antibodies (1:3000, Sigma) for 1 hour at $25^{\circ} \mathrm{C}$ in PBS-Tween. Membranes were washed again three times over 30 minutes and developed with DAB tablets (3,3'-Diaminobenzidine, Sigma).

Binding of P1 C-terminus to human proteins in ELISA. Human proteins used for ELISA include: plasma fibrinogen (Code: F3879), plasma fibronectin (Code: 11051407001), Glu-plasminogen (Code: P7999), vitronectin (Code: SRP3186), laminin (Code: L6274), and lactoferrin (Code: L1294) which were all supplied by Sigma.

Binding affinity measured by ELISA was performed as described previously ${ }^{17}$. Recombinant protein RP15 was produced as described ${ }^{55}$ and both C-terminal peptides were synthesised by Chempeptide Limited (China). P1-30 (1597TSAAKPGAPRPPVPPKPGAPKPPVQPPKKPA ${ }^{1627}$ ) without any tags, but P1-15 $\left({ }^{1613}\right.$ PGAPKPPVQPPKKPA ${ }^{1627}$ ) was sequenced with an $\mathrm{N}$-terminal biotin tag.

$15 \mu \mathrm{g} / \mathrm{ml}$ of C-terminal P1 fragments were bound to wells and incubated with different host proteins. Wells were then incubated with different antiserum raised against the different host proteins at the following dilutions (all from Sigma): anti-fibrinogen 1:3000, anti-fibronectin 1:1000, anti-plasminogen: 1:2500, anti-vitronectin 1:5000, anti-laminin 1:750, and anti-lactoferrin 1:5,000. These incubations were followed by incubations with anti-rabbit IgG (Dako) or anti-goat IgG (both 1:2,000). Detection was measured by adding Tetramethylbenzidine (Sigma) followed by $1 \mathrm{M} \mathrm{HCl}$, and absorbance was measured at $450 \mathrm{~nm}$ ( $620 \mathrm{~nm}$ as reference).

Binding of the P1 C-terminus to A549 human lung cells. Freshly grown A549 cells were immobilised in 96 -well microtitre plates as described in ${ }^{17}$. Immobilised A549 cells were incubated with $10 \mu \mathrm{g} / \mathrm{ml}$ of either RP15, P1-30, or P1-15 and binding affinity was measured with antiserum raised against RP15 (1:100) as described above. Absorbance detection at $450 \mathrm{~nm}$ is the same as described above.

Affinity chromatography of complexes that bind the P1 C-terminus. The C-terminal sequence of P1 (P1-15) was synthesised with an N-terminal biotin tag by Chempeptide Limited (China). Affinity chromatography was performed similar to the section above. In brief, $1 \mathrm{mg}$ of the peptide was added to Avidin Agarose beads for $16 \mathrm{~h}$ at $4^{\circ} \mathrm{C}$. The beads were washed four times $(5 \mathrm{ml}$ per wash) with PBS before being incubated with native A549 cell lysates (harvested in $1 \% \mathrm{w} / \mathrm{v} \mathrm{C} 7 \mathrm{BzO}$ in PBS) for $16 \mathrm{~h}$ at $4^{\circ} \mathrm{C}$. Non-binding proteins were washed from 


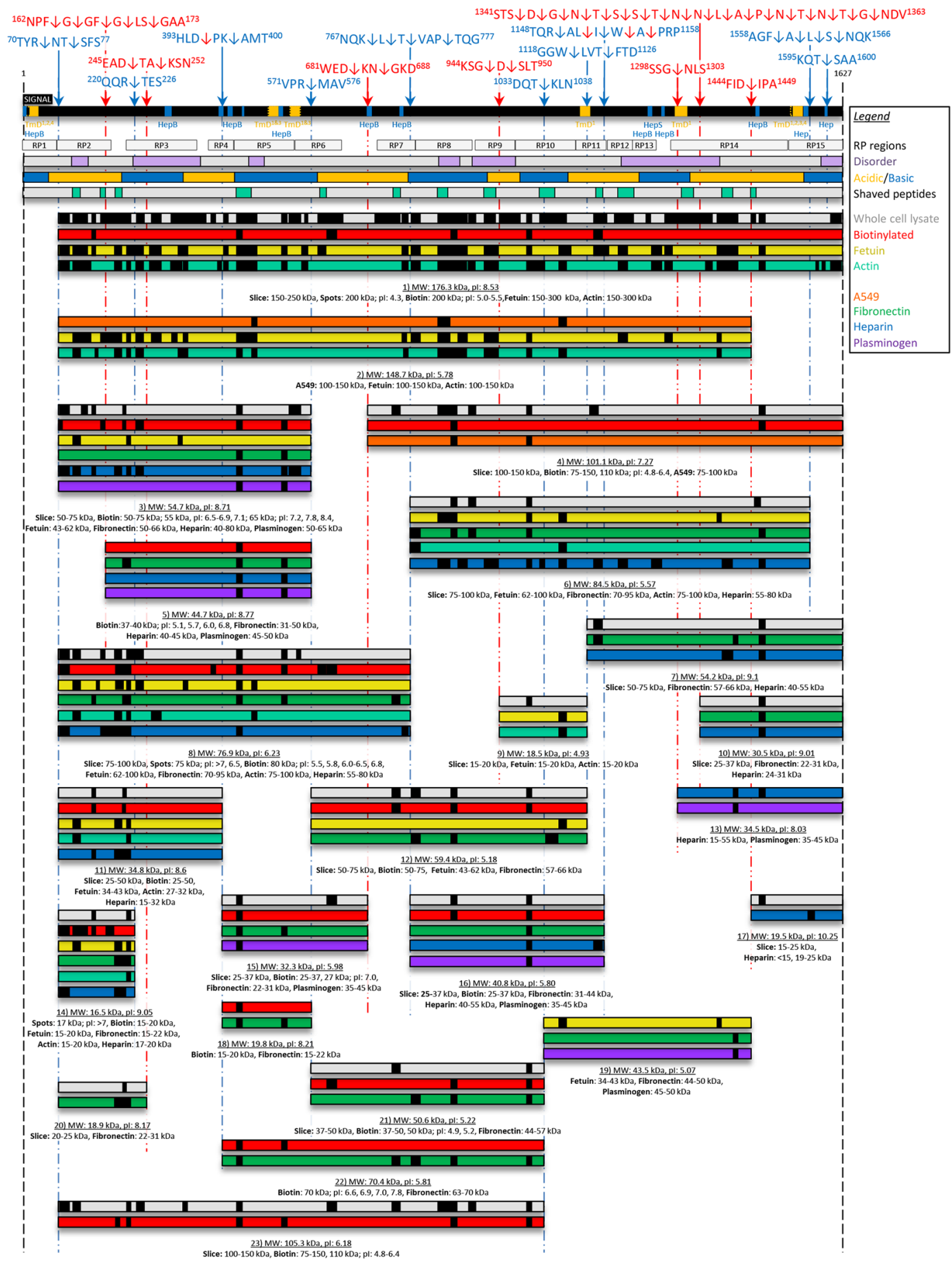

Figure 1. Cleavage map of the P1 adhesin. The full length proteoform (1627 amino acids) is shown as the black bar with cleavage sites above and fragments below this bar. Cleavage sites identified from dimethyl labelling and semi-tryptic sites are shown as the blue and red arrows, respectively. Sequences where these cleavage sites occur are also shown. Putative heparin binding sites (Hep, blue boxes, motif: X-[HRK]-[HRK]-X-[HRK]-X), heparan sulfate binding sites (Hep ${ }^{\mathrm{S}}$, blue boxes, motif: X-[HRK]-X-[HRK]-[HRK]-X), clusters of basic residues (Hep ${ }^{\mathrm{B}}$, blue boxes, motifs: X-[HRK]-X(0,2)-[HRK]-X(0,2)-[HRK]-X or X-[HRK]-X(1,3)-[HRK]-X(1,3)-[HRK]-X), and transmembrane domains $\left(\mathrm{TmD}\right.$, yellow boxes, $\mathrm{TmD}^{1}$ predicted by $\mathrm{TMpred}^{66}, \mathrm{TmD}^{2}$ previously predicted ${ }^{32}$, $\mathrm{TmD}^{3}$ previously predicted ${ }^{36}$, and $\mathrm{TmD}^{4}$ previously predicted in a $\mathrm{P} 1$ paralog ${ }^{73}$ ) are shown within the black bar. Putative transmembrane domains and the location of 15 subregions of P1 (grey 'RP' boxes) expressed as recombinant proteins from an earlier study ${ }^{55}$ are shown. Predicted disordered regions appear as purple boxes in the grey bar. Acidic and basic regions within P1 are identified as yellow and blue bars, respectively. Peptides released from surface shaving experiments and identified by mass spectrometry are shown in the light green boxes within the grey bar. Grey bars represent fragments of P1 identified during SDS-PAGE of whole cell lysates. Red bars represent fragments of P1 recovered from lysates of M. pneumoniae that have their surface proteins labelled with biotin (surface exposed fragments of P1). Peptides identified by mass spectrometry of P1 
fragments isolated from affinity chromatography of fetuin (yellow bars), actin (light blue bars), A549 surface protein complexes (orange bars), fibronectin (green bars), heparin (blue bars), and plasminogen (purple bars) are shown.

the column with four washes ( $5 \mathrm{ml}$ per wash) of PBS and protein complexes with an affinity to the peptide were eluted from the column with $7 \mathrm{M}$ urea, $2 \mathrm{M}$ thiourea, $40 \mathrm{mM}$ Tris- $\mathrm{HCl}$, and $1 \%$ (w/v) C7BzO (4 times of $2 \mathrm{ml}$ ). Eluents were concentrated with a Macrosep ${ }^{\circledR} 3 \mathrm{kDa}$ cutoff centrifugal device (Pall), precipitated with acetone, and separated by $1 \mathrm{D}-$ SDS PAGE. The whole lane was divided into sections, in-gel digested with trypsin, and analysed by LC-MS/MS as described above.

Microscale thermophoresis of P1-15 binding affinity. Binding affinities to fluorescent labelled host proteins was measured by microscale thermophoresis as described in ${ }^{72}$. Microscale thermophoresis was set to $30 \mathrm{~s}$ and samples were scanned with $40 \%, 60 \%$ and $80 \%$ MST Power. Dissociation constants were determined from generated dissociation curves with set hot/cold or thermophoresis settings. As a control, a scrambled version of the C-terminal P1 peptide (PKPPRAAPPKAPTPVPPGPASPVKKPKQAPG) was synthesised by Chempeptide Limited (China) without any tags and binding affinities was measured.

Ethical approval. Guinea pig sera used in this study was generated in a previous study ${ }^{55}$. The animal experiments in that previous study were proved by the ethical board of Landesdirektion Sachsen, Dresden, Germany (no. 24-9168.25-1).

\section{Results}

Bioinformatic analysis of the P1 adhesin. The P1 adhesin has a predicted mass of $176.3 \mathrm{kDa}$ and a $\mathrm{p} I$ of 8.53 and contains six predicted transmembrane regions and nine putative glycosaminoglycan binding sites (Fig. 1). The first transmembrane region (spanning the $\mathrm{N}$-terminus), and the last transmembrane region (spanning the C-terminus) have been identified in previous studies of $\mathrm{P} 1^{32,36,66}$, and a P1 paralog of Mycoplasma genitalium $^{73}$. The glycosaminoglycan binding sites consist of reiterated copies of positively charged amino acids that are likely to be important in interactions with sulphated derivatives of heparin and heparan sulfate. Analysis of P1 using PONDR ${ }^{\circledR}$ identified seven putative disordered regions that span at least 30 amino acids (Fig. 1). Modules in $\mathrm{P} 1$ enriched in acidic $(\mathrm{E}, \mathrm{K})$ and basic $(\mathrm{K}, \mathrm{R}, \mathrm{H})$ amino acids were identified. Disordered region and protein modules enriched in acidic and basic amino acids have been described in adhesin families in the respiratory pathogen $M$. hyopneumoniae and these were influential in the location of a subset of important cleavage sites ${ }^{60-62,74}$. We confirmed the precise location of 17 cleavage sites in P1 (shown below), 11 of which reside in predicted regions of disorder (Fig. 1). Cleavage sites did not seem to be over-represented in acidic or basic domains.

The $\mathrm{P} 1$ adhesin is processed extensively on the $\mathrm{M}$. pneumoniae cell surface. P1 peptides identified by LC-MS/MS analyses of size fractionated M. pneumoniae lysates identified 23 proteoforms ranging in size from 17 to $176 \mathrm{kDa}$ including the full length proteoform without the $\mathrm{N}$-terminal signal sequence (Fig. 1). The full length and an additional 16 smaller proteoforms of P1 were identified by LC-MS/MS of size fractionated cell lysates separated by SDS-PAGE (grey bars; Fig. 1). The migration behaviour of these 17 proteoforms of P1 was consistent with masses predicted by ProtParam ${ }^{65}$. Trypsin shaving of the M. pneumoniae cell surface released trypsin accessible peptides (green boxes within a grey bar in Fig. 1) that span most of the adhesin indicating that $\mathrm{P} 1$ is exposed on the cell surface. This was consistent with LC-MS/MS analysis of size-fractionated biotinylated proteins that were first enriched using avidin chromatography which identified 14 proteoforms (full and fragments 2, 3, 5, 7, 10, 11, 13, 14, 16, 17, 20, 21, and 22) of P1 (red bars in Fig. 1). These data suggest that cleaved P1 proteoforms are surface accessible.

Several other proteoforms of P1 were identified by LC-MS/MS of protein bands digested in-gel from affinity experiments. Two proteoforms of P1 with masses of $149 \mathrm{kDa}$ (fragment 1) and $101 \mathrm{kDa}$ (fragment 3 ) (orange bars in Fig. 1) were identified from columns coupled with biotinylated A549 surface protein complexes suggesting that large $\mathrm{P} 1$ proteoforms with multiple binding domains are required to bind surface receptors on A549 cells. Eluents derived from columns coupled with fetuin and actin were particularly useful for identifying the full length protein and fragments $1,2,4,7,8,10,11,16$ and 18 of P1. Nine fragments $(1,2,4,7,8,10,11,16$, and 18; yellow bars in Fig. 1) were recovered from columns coupled with fetuin, and six fragments $(1,4,7,8,10$, and 16; light blue bars in Fig. 1) were recovered from columns coupled with actin. Six fragments $(2,5,12,13,14,18)$ were identified from columns coupled with plasminogen (purple bars in Fig. 1). For the eleven fragments identified from heparin chromatography (blue bars in Fig. 1; fragments: 2, 4, 5, 6, 7, 9, 10, 12, 14, 15, and 16), only two (fragment 14 and 16) did not contain any of the predicted glycosaminoglycan binding motifs identified with ScanProsite. Fifteen fragments $(2,4,5,6,7,9,11,13,14,16,17,18,19,20$, and 21) were identified in eluents from columns coupled with fibronectin (green bars in Fig. 1).

A global M. pneumoniae dimethyl labelling approach was used to identify internal neo- $\mathrm{N}$ termini. Ten cleavage sites were identified in P1 using this approach (Table 1, blue arrows in Fig. 1). Semi-tryptic peptides, defined as peptides with only one tryptic end (Table 1, red arrows in Fig. 1) were also identified, implying seven additional cleavage sites in P1. Four distinct sites in P1 showed evidence that surface accessible amino-peptidases may alter neo-N-termini (Fig. 1 and Table 1): ${ }^{162} \mathrm{NPF} \downarrow \mathrm{G} \downarrow \mathrm{GF} \downarrow \mathrm{G} \downarrow L S \downarrow \mathrm{GAA}^{173}$ (cleavage site 2), ${ }^{767} \mathrm{NQK} \downarrow \mathrm{L} \downarrow \mathrm{T} \downarrow$ VAP $\downarrow$ TQG ${ }^{777}$ (cleavage site 8), ${ }^{1148} \mathrm{TQR} \downarrow \mathrm{AL} \downarrow \mathrm{I} \downarrow \mathrm{W} \downarrow \mathrm{A} \downarrow \mathrm{PRP}^{1158}$ (cleavage site 12), and ${ }^{1558} \mathrm{AGF} \downarrow \mathrm{A} \downarrow \mathrm{L} \downarrow \mathrm{S} \downarrow N \mathrm{NQK} \mathrm{K}^{1566}$ (cleavage site 16) in a manner that is similar to amino-peptidase processing events reported in the major adhesin families in $M$. hyopneumoniae ${ }^{57,64,74,75}$. A large predicted disorder region spanning 196 amino acids near the carboxyl terminal 


\begin{tabular}{|c|c|c|c|c|}
\hline No. & ID & Peptide Sequence & Score & E-value \\
\hline & & N-terminal dimethyl labelled peptides & & \\
\hline \multirow[t]{2}{*}{1} & N1 & $\mathrm{R}^{.7} \underline{\underline{\mathbf{N}} T S F S S L P L T G E N P G A W A L V R}{ }^{93} . \mathrm{D}$ & 107 & $6.20 \mathrm{E}^{-09}$ \\
\hline & $\mathrm{N} 2$ & $\mathrm{~T}^{75} \underline{\text { SFSSLPLTGENPGAWALVR }}{ }^{93} . \mathrm{D}$ & 26 & 0.039 \\
\hline 3 & N3 & 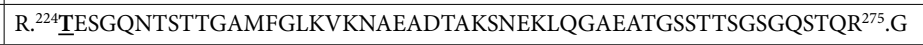 & 72 & $6.60 \mathrm{E}^{-07}$ \\
\hline 5 & $\mathrm{~N} 4$ & K. ${ }^{398} \underline{\text { AMTANYPPSWR }}{ }^{408} \cdot \mathrm{T}$ & 67 & $5.70 \mathrm{E}^{-05}$ \\
\hline 6 & N5 & R. ${ }^{574} \underline{\text { MAVAGAKFVGR }}{ }^{584} . \mathrm{E}$ & 62 & $5.00 \mathrm{E}^{-04}$ \\
\hline \multirow[t]{4}{*}{8} & N6 & $\mathrm{K}^{.770} \underline{{ }^{7}}$ TVAPTQGTNWSHFSPTLSR ${ }^{789} . \mathrm{F}$ & 121 & $7.00 \mathrm{E}^{-11}$ \\
\hline & N7 & L. $^{771} \underline{\text { TVAPTQGTNWSHFSPTLSR }}{ }^{789} \cdot \mathrm{F}$ & 77 & $8.10 \mathrm{E}^{-07}$ \\
\hline & N8 & $\mathrm{T}^{772} \underline{V}$ APTQGTNWSHFSPTLSR ${ }^{789} \cdot \mathrm{F}$ & 64 & $1.00 \mathrm{E}^{-05}$ \\
\hline & N9 & P. ${ }^{775}$ TQGTNWSHFSPTLSR ${ }^{789} \cdot \mathrm{F}$ & 35 & $5.30 \mathrm{E}^{-03}$ \\
\hline 10 & N10 & T. ${ }^{1036} \underline{K} L N L P A Y G E V N G L L N P A L V E T Y F G N T R{ }^{1062} . A$ & 173 & $7.10 \mathrm{E}^{-16}$ \\
\hline \multirow[t]{2}{*}{11} & N11 & W..$^{1121} \underline{\text { LVTFTDFVKPR }}{ }^{1131} \cdot \mathrm{A}$ & 58 & $7.20 \mathrm{E}^{-05}$ \\
\hline & N12 & $\mathrm{T}^{1124}{ }^{112}{ }^{2} \mathrm{DFVKPR}^{1131} \cdot \mathrm{A}$ & 40 & $5.70 \mathrm{E}^{-03}$ \\
\hline \multirow[t]{2}{*}{12} & N13 & R. ${ }^{1151}$ ALIWAPRPWAAFR ${ }^{1163} \cdot G$ & 36 & $1.20 \mathrm{E}^{-03}$ \\
\hline & N14 & I. ${ }^{1154} \underline{W} A P R P W A A F R{ }^{1163} \cdot G$ & 27 & $2.10 \mathrm{E}^{-03}$ \\
\hline \multirow[t]{4}{*}{16} & N15 & F. $^{1561} \underline{\text { ALSNQKVDVLTKAVGSVFKEIINR }}{ }^{1584} \cdot \mathrm{T}$ & 160 & $1.70 \mathrm{E}^{-14}$ \\
\hline & N16 & A. ${ }^{.1562} \underline{L}$ LNQKVDVLTKAVGSVFKEIINRR ${ }^{1584} . \mathrm{T}$ & 158 & $1.30 \mathrm{E}^{-13}$ \\
\hline & N17 & L. ${ }^{1563} \underline{\underline{S}}$ LSNQKVDVLTKAVGSVFKEIINR ${ }^{1584} \cdot \mathrm{T}$ & 184 & $3.90 \mathrm{E}^{-16}$ \\
\hline & N18 & $\mathrm{S}^{\mathrm{S}{ }^{1564} \underline{\mathrm{N}} \mathrm{QKVDVLTKAVGSVFKEIINR}{ }^{1584} \cdot \mathrm{T}}$ & 102 & $4.60 \mathrm{E}^{-09}$ \\
\hline \multirow[t]{2}{*}{17} & N19 & T. $^{1598} \underline{\mathbf{S} A A K P G A P R P P V P P K P G A P K P P V Q P P K K P A ~}{ }^{1627}$ & 58 & $4.50 \mathrm{E}^{-06}$ \\
\hline & & N-terminal semi-tryptic peptides & & \\
\hline \multirow[t]{5}{*}{2} & S1 & $\mathrm{F}^{165}{ }^{16 G F G L S G A A P Q Q W N E V K N K V P V E V A Q D P S N P Y R ~}{ }^{197} . \mathrm{F}$ & 39 & $2.10 \mathrm{E}^{-03}$ \\
\hline & S2 & G. ${ }^{166}$ GFGLSGAAPQQWNEVKNKVPVEVAQDPSNPYR ${ }^{197} . \mathrm{F}$ & 34 & $3.20 \mathrm{E}^{-03}$ \\
\hline & S3 & F. $^{168} \underline{\text { GLSGAAPQQWNEVKNKVPVEVAQDPSNPYR }}{ }^{197} . \mathrm{F}$ & 42 & 0.037 \\
\hline & S4 & G. ${ }^{169}$ LSGAAPQQWNEVKNKVPVEVAQDPSNPYR ${ }^{197} . \mathrm{F}$ & 59 & $5.00 \mathrm{E}^{-06}$ \\
\hline & S5 & S. ${ }^{171}$ GAAPQQWNEVKNKVPVEVAQDPSNPYR ${ }^{197} \cdot \mathrm{F}$ & 46 & $3.0 \mathrm{E}^{-04}$ \\
\hline \multirow[t]{2}{*}{4} & S6 & D. $^{248} \underline{\underline{T}}$ AKSNEKLQGAEATGSSTTSGSGQSTQR ${ }^{275} \cdot \mathrm{G}$ & 126 & $1.00 \mathrm{E}^{-11}$ \\
\hline & S7 & A. ${ }^{250} \underline{\text { AKSNEKLQGAEATGSSTTSGSGQSTQR }}{ }^{275} \cdot \mathrm{G}$ & 80 & $4.20 \mathrm{E}^{-07}$ \\
\hline 5 & S8 & D. ${ }^{396}$ PKAMTANYPPSWR ${ }^{408} \cdot \mathrm{T}$ & 103 & $1.40 \mathrm{E}^{-08}$ \\
\hline \multirow[t]{2}{*}{7} & S9 & D. ${ }^{684} \underline{K}$ NGKDDAKYIYPYR ${ }^{694} . Y$ & 58 & $1.90 \mathrm{E}^{-04}$ \\
\hline & S10 & N. ${ }^{686}{ }^{G K D D A K Y I Y P Y R}{ }^{694} . Y$ & 61 & $2.00 \mathrm{E}^{-04}$ \\
\hline \multirow[t]{4}{*}{12} & S11 & L. $^{1153}{ }^{11 W A P R P W A A F R ~}{ }^{1163} \cdot \mathrm{G}$ & 56 & $2.00 \mathrm{E}^{-04}$ \\
\hline & S12 & I. $^{1156} \underline{\mathbf{W}}$ APRPWAAFR ${ }^{1163} \cdot G$ & 46 & $3.90 \mathrm{E}^{-03}$ \\
\hline & S13 & $\mathrm{W}^{1154}{ }^{119} \mathrm{APPWAAFR}{ }^{1163} \cdot \mathrm{G}$ & 49 & $3.30 \mathrm{E}^{-04}$ \\
\hline & S14 & A. ${ }^{1155} \underline{\text { PRPWAAFR }}{ }^{1163} . \mathrm{G}$ & 46 & $3.10 \mathrm{E}^{-03}$ \\
\hline \multirow[t]{18}{*}{14} & S15 & S. ${ }^{1344} \underline{\mathbf{D}}$ GNTSSTNNLAPNTNTGNDVVGVGR ${ }^{1368} \cdot \mathrm{L}$ & 90 & $1.20 \mathrm{E}^{-08}$ \\
\hline & S16 & D. $^{1345}{ }^{134 T S S T N N L A P N T N T G N D V V G V G R ~}{ }^{1368}$. L $^{2}$ & 192 & $8.00 \mathrm{E}^{-17}$ \\
\hline & S17 & G. ${ }^{1346}{ }^{\text {NTSSTNNLAPNTNTGNDVVGVGR }}{ }^{1368} . \mathrm{L}$ & 158 & $1.20 \mathrm{E}^{-13}$ \\
\hline & S18 & N. ${ }^{1347} \underline{T}$ SSTNNLAPNTNTGNDVVGVGR ${ }^{1368} \cdot \mathrm{L}$ & 154 & $6.00 \mathrm{E}^{-13}$ \\
\hline & S19 & $\mathrm{T}^{1348} \underline{\text { SSTNNLAPNTNTGNDVVGVGR }}{ }^{1368} . \mathrm{L}$ & 121 & $7.90 \mathrm{E}^{-10}$ \\
\hline & S20 & S. ${ }^{1349} \underline{\text { STNNLAPNTNTGNDVVGVGR }}{ }^{1368} \cdot \mathrm{L}$ & 126 & $1.90 \mathrm{E}^{-10}$ \\
\hline & S21 & 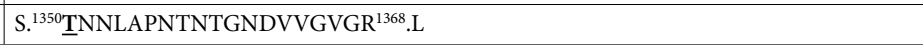 & 121 & $4.60 \mathrm{E}^{-11}$ \\
\hline & S22 & T. ${ }^{1351} \underline{\text { NNLAPNTNTGNDVVGVGR }}{ }^{1368} . \mathrm{L}$ & 117 & $4.20 \mathrm{E}^{-10}$ \\
\hline & S23 & N. ${ }^{1352} \underline{\text { NLAPNTNTGNDVVGVGR }}{ }^{1368} . \mathrm{L}$ & 132 & $1.00 \mathrm{E}^{-11}$ \\
\hline & S24 & N. ${ }^{1353} \underline{\text { LAPNTNTGNDVVGVGR }}{ }^{1368} \cdot \mathrm{L}$ & 118 & $6.30 \mathrm{E}^{-10}$ \\
\hline & S25 & L. ${ }^{1354} \underline{\text { APNTNTGNDVVGVGR }}{ }^{1368} \cdot \mathrm{L}$ & 104 & $4.00 \mathrm{E}^{-09}$ \\
\hline & S26 & A. ${ }^{.1355} \underline{\mathbf{P} N T N T G N D V V G V G R}{ }^{1368} . \mathrm{L}$ & 108 & $9.70 \mathrm{E}^{-10}$ \\
\hline & S27 & P. ${ }^{1356} \underline{\mathbf{N} T N T G N D V V G V G R}{ }^{1368} \cdot \mathrm{L}$ & 74 & $9.20 \mathrm{E}^{-06}$ \\
\hline & S28 & $\mathrm{N}^{1.357} \underline{\text { TNTGNDVVGVGR }}{ }^{1368} \cdot \mathrm{L}$ & 85 & $3.40 \mathrm{E}^{-06}$ \\
\hline & S29 & T. $^{1358} \underline{\mathbf{N} T G N D V V G V G R}{ }^{1368} \cdot \mathrm{L}$ & 80 & $1.90 \mathrm{E}^{-06}$ \\
\hline & S30 & $\mathrm{N} \cdot{ }^{1359} \underline{\mathrm{T}}$ GNDVVGVGR ${ }^{1368} \cdot \mathrm{L}$ & 59 & $3.00 \mathrm{E}^{-04}$ \\
\hline & S31 & 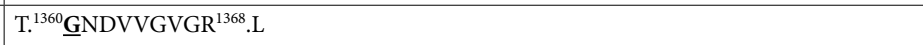 & 46 & $2.10 \mathrm{E}^{-03}$ \\
\hline & S32 & $\mathrm{GG}^{1361} \underline{\mathbf{N} D V V G V G R}{ }^{1368} \cdot \mathrm{L}$ & 52 & $4.40 \mathrm{E}^{-03}$ \\
\hline \multirow[t]{2}{*}{15} & S33 & D. ${ }^{1447} \underline{I} P A S V N P K M V R{ }^{1457} . \mathrm{L}$ & 62 & $2.80 \mathrm{E}^{-05}$ \\
\hline & & C-terminal semi-tryptic peptides & & \\
\hline 2 & & R. $^{137}$ ALYDLDFSKLNPQTPTRDQTGQITFNPF $\underline{G}^{165} \cdot G$ & 35 & 0.001 \\
\hline 4 & & R. ${ }^{224}$ TESGQNTSTTGAMFGLKVKNAEAD $\underline{2}^{247} \cdot \mathrm{T}$ & 102 & $3.70 \mathrm{E}^{-09}$ \\
\hline
\end{tabular}




\begin{tabular}{|c|c|c|c|c|}
\hline No. & ID & Peptide Sequence & Score & E-value \\
\hline 5 & & R. $^{386}$ TAIDRVDHLD $^{395} \cdot \mathrm{P}$ & 38 & $6.40 \mathrm{E}^{-03}$ \\
\hline \multirow[t]{2}{*}{9} & & R. $^{224}{ }^{N D K A S S G Q S D E N H T K F T S A T G M D Q Q G Q S G T S A G N P D S L K Q D N I S K S G ~}{ }^{246} \cdot \mathrm{D}$ & 57 & $1.10 \mathrm{E}^{-05}$ \\
\hline & & R. $^{224}$ NDKASSGQSDENHTKFTSATGMDQQGQSGTSAGNPDSLKQDNISKSG $\underline{D}^{247} . S$ & 68 & $3.50 \mathrm{E}^{-06}$ \\
\hline 13 & & R. $^{1273}$ QSFGTDHSTQPQPQSLKTTTPVFGTSS $\underline{G}^{1300} \cdot \mathrm{N}$ & 27 & $6.20 \mathrm{E}^{-03}$ \\
\hline
\end{tabular}

Table 1. N-terminal dimethylated peptides identified in P1 adhesin by LC-MS/MS. Exact site within the peptide is indicated by the bold underlined amino acid. Amino acid positions denote the start and end of the peptides. The peptides listed are the highest scores identified from 4 biological replicates analysed separately using Sciex 5600 and Thermo Scientific Q Exactive ${ }^{\mathrm{TM}}$ mass spectrometers. All peptides have expectation values $<0.05$.

A
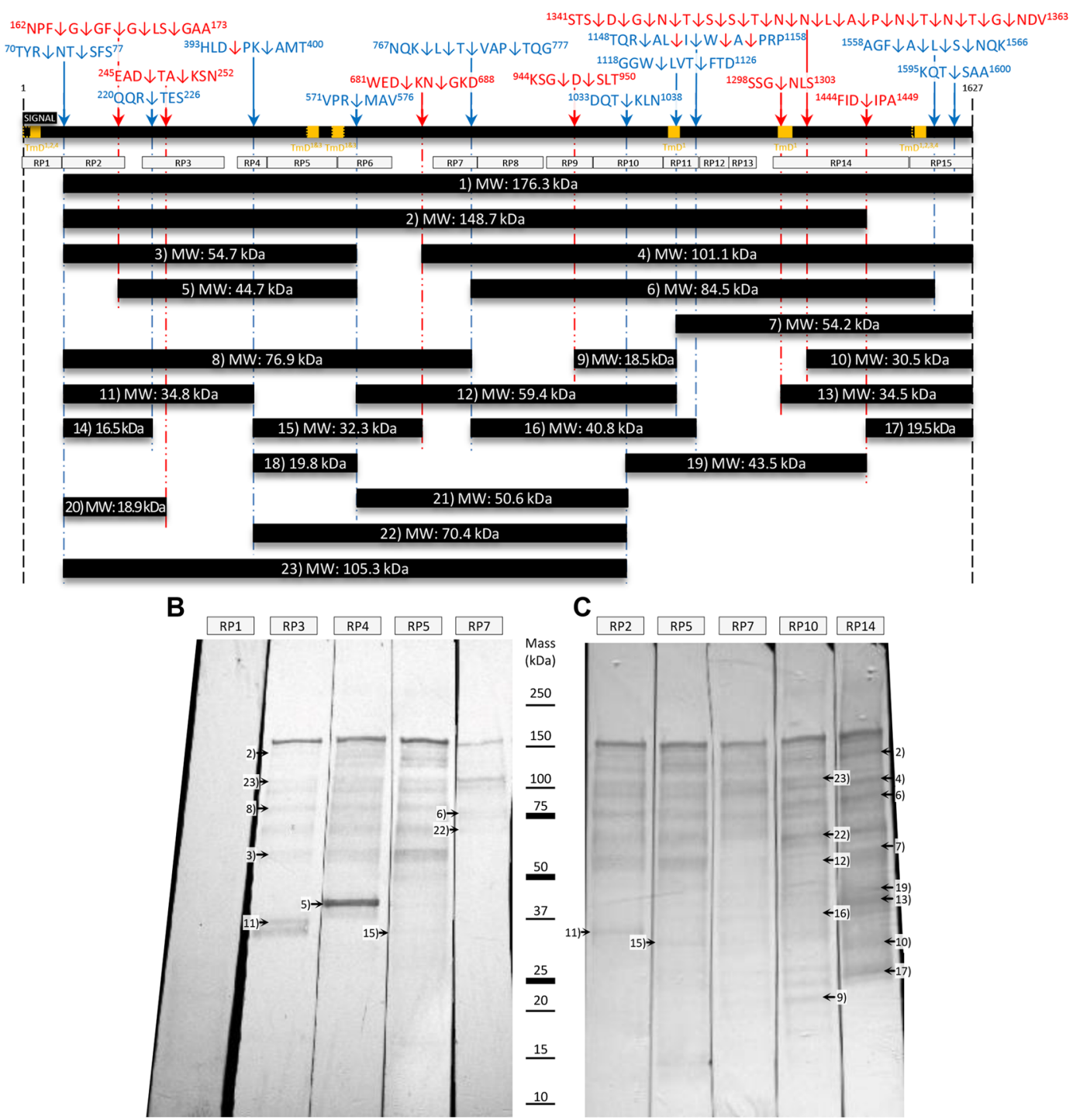

Figure 2. Immunoblots of cell lysates of M. pneumoniae probed with sera raised against regions within P1. Sera raised against 15 different regions ('RP' boxes) of P1 were a gift from R. Dumke ${ }^{55}$. (Top panel) Simplified cleavage map depicting the $\mathrm{P} 1$ adhesin, cleavage sites, and the 15 regions of $\mathrm{P} 1$ that have been previously cloned and expressed as recombinant fragments in E. coli ${ }^{55}$. The mass of full length and smaller proteoforms of $\mathrm{P} 1$ as predicted by ProtParam ${ }^{65}$. (Bottom panel) Immunoblots depicting M. pneumoniae cell lysate probed with the panel of anti-recombinant P1 sera. All the immunoblot lanes are part of the same blot. The membrane was blocked and then sliced to separate lanes before incubating with the described P1 sera. (Bottom right) Immunoblots with the intensity adjusted to highlight low abundant bands. Proteins migrating with masses similar to P1 proteoforms identified by LC-MS/MS have been marked on the immunoblot. 


\begin{tabular}{|c|c|c|}
\hline Name & Sequence & Source \\
\hline P1-15 & ${ }^{1613}$ PGAPKPPVQPPKKPA ${ }^{1627}$ & This study \\
\hline P1-30 & ${ }^{1597}{ }^{T S A A K P G A P R P P V P P K P G A P K P P V Q P P K K P A ~}{ }^{1627}$ & This study \\
\hline RP15 & $\begin{array}{l}{ }^{1521} \text { DYVLPLAITVPIVVIVLSVTLGLAIGIPMHKNKQALKAGF } \\
\text { ALSNQKVDVLTKAVGSVFKEIINRTGISQAPKRLKQTSAAKPGAPRPPVPPKPGAPKPPVQPPKKPA }{ }^{1627}\end{array}$ & 55 \\
\hline
\end{tabular}

Table 2. The C-terminal fragments used in this study.

of $\mathrm{P} 1$ represents a fifth site for high amino-peptidase activity with 18 neo-N-termini residing between amino acid positions 1343 - 1361 (cleavage site 14 in Table 1; sequence: ${ }^{1341}$ STS $\downarrow D \downarrow G \downarrow N \downarrow T \downarrow S \downarrow S \downarrow T \downarrow N \downarrow N \downarrow L \downarrow A \downarrow P \downarrow N \downarrow T \downarrow N$ $\left.\downarrow T \downarrow G \downarrow N D V^{1363}\right)$.

Immunoblots of M. pneumoniae cell lysates probed individually with sera raised against the 15 recombinant regions spanning $\mathrm{P}^{55}$ showed complex banding profiles (Fig. 2). RP1 antiserum that targeted the signal sequence (first 59 amino acids) failed to identify P1 proteoforms suggesting that the signal peptide is destroyed during the early stages of processing of P1 and was also used as a secondary negative control (Fig. 2B). RP3, RP4, RP5, and RP7 span the first half of P1 and the immunoblots detected the full length protein and proteoforms consistent with those representing P1 fragments 1, 2, 5, 7, 10, 13, 21, and 22 (Fig. 2B). P1 fragment 5 was identified in great abundance in RP4 sera, but no band was detected in RP3 or RP5. This could possibly be due to changes to exposed epitopes created from cleavage ${ }^{76-78}$, though further investigation is required. RP2, RP5, RP7 (higher antibody concentration), RP10, and RP14 sera revealed the full length adhesin and P1 fragments 1, 3, 4, 6, 8, 9, 11, $12,13,14,15,18,21$, and 22 (Fig. 2C). Fragments of P1 that were not identified with confidence were 16, 17, 19, and 20. Data presented in Fig. 2B,C suggest that processing of P1 is complex.

Functional analysis of the C-terminal tail of P1. Dimethyl labelling data indicated that the carboxy-terminal 30 residues of $\mathrm{P} 1$ is released by a cleavage event at serine ${ }^{1598}$ (cleavage site 17 in Table 1 , sequence: ${ }^{1595} \mathrm{KQT} \downarrow S A A^{1600}$ ). The $\mathrm{C}$-terminal peptide has a composition comprising five alanine, five lysine, and thirteen proline residues. This C-terminal region also shares sequence identity (53.1\%) with the carboxy-terminal 31 residues of Mpn142. Furthermore, the final 15 residues of P1 shares $73.3 \%$ sequence identity with the last 14 residues of Mpn142 (11 identical positions). The C-terminal 30 amino acids (named P1-30: ${ }^{1597}$ TSAAKPGAPRPPVPPKPGAPKPPVQPPKKPA ${ }^{1627}$ ), and the C-terminal 15 amino acids (named P1-15 ${ }^{1613}$ PGAPKPPVQPPKKPA ${ }^{1627}$ ) were synthesised chemically (Table 2; Chempeptide Limited, China) and an $\mathrm{N}$-terminal biotin tag was added to the P1-15 peptide. Microtitre binding assays revealed that P1-15, P1-30, and the recombinant protein, RP15 $5^{55}$, bind a range of host molecules in a dose dependent manner (Fig. 3). M. pneumoniae cells and RP15 bound lactoferrin, vitronectin, plasminogen, fibronectin, and fibrinogen. Only $M$. pneumoniae cells bound laminin. P1-30 bound fibronectin, fibrinogen and plasminogen in a dose dependent manner but failed to bind laminin. P1-15 only bound plasminogen in a dose dependent manner but also bound to vitronectin but failed to bind laminin, lactoferrin, fibronectin, and fibrinogen (Fig. 3). Compared with P1-30 and P1-15, the C-terminal 106 amino acids of P1 represented by RP15 consistently showed the most consistent and most diverse binding capabilities for the panel of host proteins tested here suggesting that multiple binding domains increase the binding capabilities of P1 proteoforms. Consistent with this hypothesis, RP15 spans two putative glycosaminoglycan binding motifs (underlined motifs in Table 2) that are absent in P1-30 and P1-15.

To investigate whether binding was due to the specific amino acid sequence or to amino acid composition, microscale thermophoresis was performed on P1-30 and a scrambled version of P1-30 (PKPPRAAPPKAPTPVPPGPASPVKKPKQAPG). P1-30 had a medium binding affinity for plasminogen $\left(\mathrm{K}_{\mathrm{D}}=554 \pm 2.1 \mathrm{nM}\right)$ and a medium/low binding affinity for fetuin $\left(\mathrm{K}_{\mathrm{D}}=2.4 \pm 0.7 \mu \mathrm{M}\right)$. No binding affinity could be detected for the scrambled peptide (Fig. 4).

Microtitre binding assays were also employed to determine the binding capabilities of regions spanning the C-terminus of P1 to A549 human epithelial cells (Fig. 5). Recombinant pyruvate dehydrogenase subunit B of $M$. pneumoniae (rPdhB; positive control ${ }^{16}$ ) and RP15 bound immobilised A549 cells, but not P1-30. We were not able to determine if $\mathrm{P} 1-15$ bound using this assay because we lacked reagents that could detect this peptide.

To overcome this experimental limitation and to attempt to identify potential binding partners for P1-15, we designed an affinity bait-prey experiment. The biotinylated P1-15 was coupled to avidin agarose and, in parallel with uncoupled avidin-agarose (negative control), were exposed to a native A549 cell lysate as described in Methods, washed and eluants were characterised by SDS-PAGE and LC-MS/MS (Fig. S1). Three protein bands identified in eluents from avidin-agarose coupled with biotinylated P1-15 that were absent in the control were analysed by LC-MS/MS (Fig. S1). LC-MS/MS analysis of slice 1 and 2 identified tryptic peptides that mapped to the intermediate filament cytoskeletal proteins cytokeratin 7 (Mascot score $=1157)$, cytokeratin 8 (Mascot score $=2737 \& 1486$ ), cytokeratin 18 (Mascot score $=2592$ ), and vimentin (Mascot score =617) (Fig. S1). Tryptic peptides to these filament proteins were not identified in the control experiment. Tryptic peptides identified in slice 3 identified glyceraldehyde-3-phosphate dehydrogenase, however, this protein was also identified in the eluents from the control and was not considered further as a potential binding partner with P1-15.

\section{Discussion}

M. pneumoniae binds diverse host cell proteins including plasminogen, fibronectin, vitronectin, fibrinogen, lactoferrin, glycosaminoglycans, and sialoglyconjugates ${ }^{9-17}$.

The $\mathrm{P} 1$ adhesin and proteins it associates with at the tip of the attachment organelle are central to binding interactions that enable M. pneumoniae to target host cell receptors and is likely to contain binding domains 

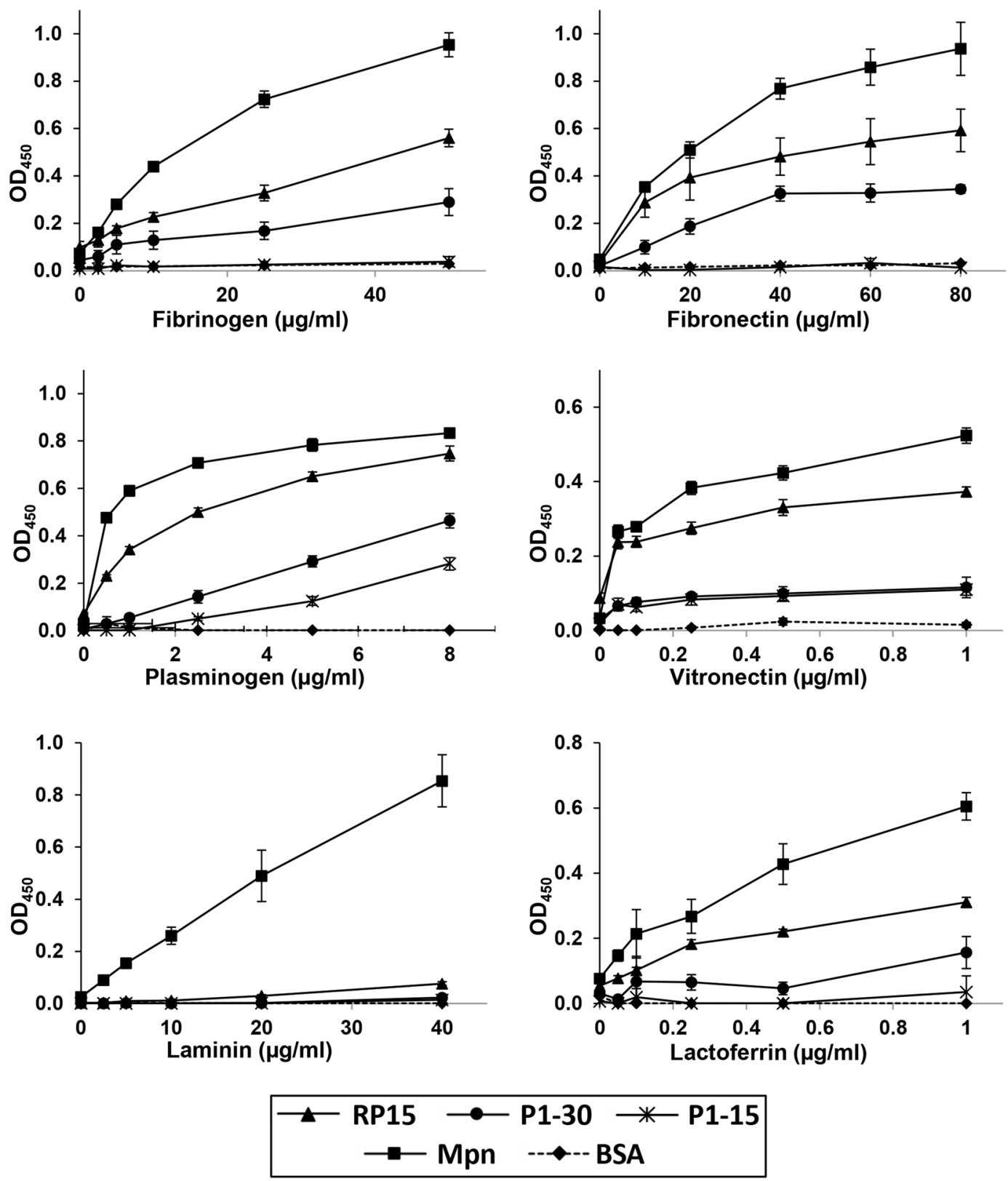

Figure 3. Concentration-dependent binding of the C-terminus of $\mathrm{P} 1$ to different human proteins. Microtitre plate binding assays were used to measure the binding abilities of RP15, P1-30, and P1-15 to human plasminogen and to different components of the human extracellular matrix. Bovine serum albumin (BSA) and whole cell lysate proteins of $M$. pneumoniae (Mpn) were used as a negative and positive control, respectively. Results are shown from a single experiment with a mean and standard deviation of eight replicates. The experiment was independently repeated twice.

for some or all of these host molecules. Here we show that Mpn141 is processed extensively generating 23 proteoforms and that many proteoforms are retained on affinity matrices loaded with different host molecules and mimics of regions of host proteins including fetuin, fibronectin, actin, heparin, and plasminogen. Microtitre plate binding assays and microscale thermophoresis assays confirmed several of these preliminary findings and showed that the C-terminal region of P1 binds vitronectin, fibrinogen and fibronectin. Apart from removal of a 59 amino acid $\mathrm{N}$-terminal leader peptide, only a $\sim 40 \mathrm{kDa}$ carboxyl terminal truncated fragment of P1 (potentially representing fragment 18 from this study), that forms a complex with full length $\mathrm{P} 1$ protein, and other accessory proteins has been reported previously ${ }^{33}$ but earlier immunoblotting studies with anti-P1 monospecific antisera identified numerous smaller proteoforms of P1 that were not characterised ${ }^{2}$. Dimethyl labelling experiments enabled us to map the precise location of cleavage events in P1 (Table 1). P1 proteoforms are likely generated by proteases on the cell surface of M. pneumoniae or associated with the protein translocation machinery but their identities have not been confirmed. Biotinylation studies identified 13 proteoforms of $\mathrm{P} 1$ that were accessible on the surface of $M$. pneumoniae and our surface labelling and trypsin shaving experiments indicate that the 

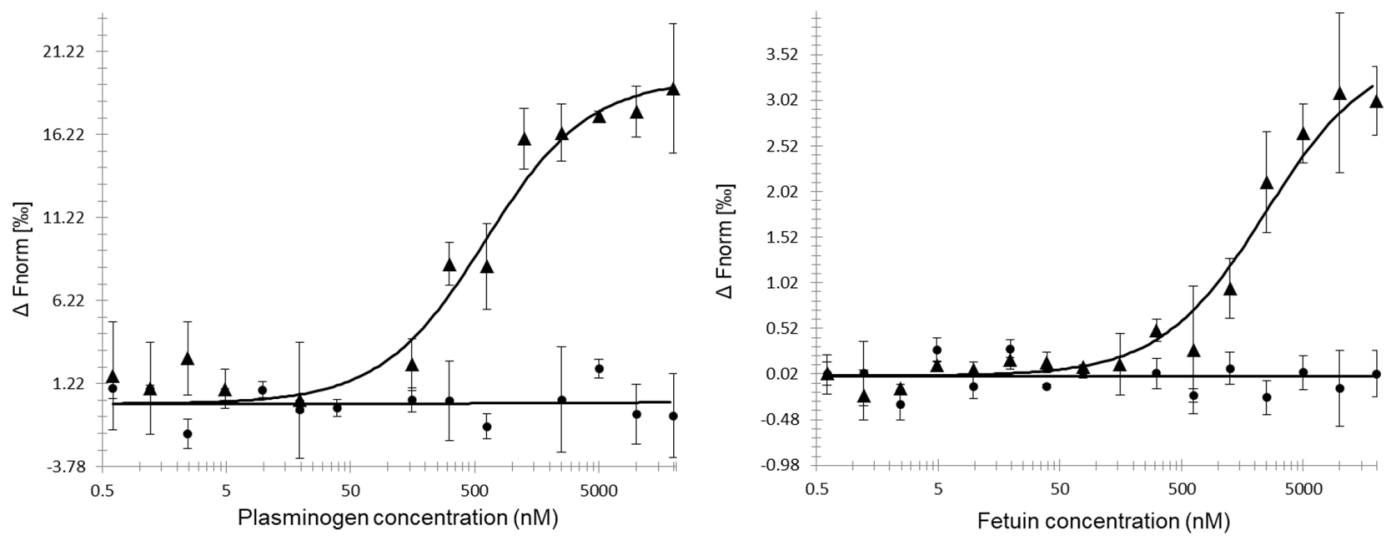

A P1-30 Scrambled peptide

Figure 4. Plasminogen and fetuin binding by P1-30 using microscale thermophoresis. Left: Thermophoretic output representing P1-30 (triangles) binding to plasminogen with a $\mathrm{K}_{\mathrm{D}}$ of $554 \mathrm{nM}$. A scrambled version of P1-30 (circles) could not be assigned a $K_{D}$ value. Right: Thermophoretic output representing P1-30 binding to fetuin with a $K_{D}$ of $2 \mu \mathrm{M}$. The scrambled peptide could not be assigned a $K_{D}$ value.

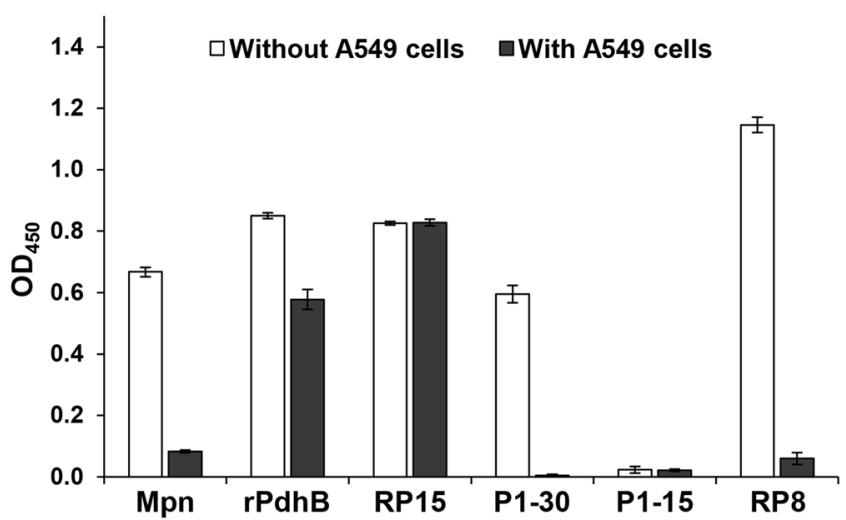

Figure 5. Binding of the C-terminus of P1 to immobilized A549 cells. Proteins, peptides, or A549 cells were immobilised in wells of a 96-well plate and binding was measured in a microtitre plate binding assay. 'Without A549' cells: protein and peptides were immobilised and detected by corresponding antisera (peptides with anti-RP15). 'With A549 cells': A549 cells were immobilised first before incubating with proteins and peptides. Whole antigen of M. pneumoniae (Mpn), recombinant PdhB, and RP8 served as positive and negative controls, respectively ${ }^{17}$. Bars represent mean and standard deviation of eight replicates from a single experiment. The experiment was independently repeated twice.

proteoforms remain attached to the extracellular side of $M$. pneumoniae cell membranes. Our data is consistent with electron micrographs of M. pneumoniae immunostained with ferretin-labelled anti-P1 antibodies that depict gold particles at: i) the tip of the attachment organelle; ii) along the shaft of this structure; iii) at sites along the cell body; and iv) at sites distant from the M. pneumoniae membrane ${ }^{2}$. It is not known if some proteoforms are excreted into the extracellular milieu but it is conceivable that processing of P1 occurs after translocation and the fragments may remain anchored to the surface via the predicted C-terminal transmembrane domain similarly seen in P40 and P90 of M. pneumoniae ${ }^{27}$. Consistent with this view, we were unable to find tryptic peptides that mapped to the putative leader peptide residing in the $\mathrm{N}$-terminus of $\mathrm{P} 1$ or in the bioinformatically predicted transmembrane domains, or the well characterised C-terminal transmembrane domain. However, we did find tryptic peptides in the bioinformatically predicted transmembrane domain located around residue 1294.

Regions in P1 have been extensively characterised in an earlier study ${ }^{55}$. Highly immunogenic regions and adherence mediating regions were found distributed throughout P1 particularly in the carboxy-terminal half of the molecule ${ }^{55}$. Sera from patients infected with M. pneumoniae bound to regions in P1 that were not responsible for adherence ${ }^{55}$. It is conceivable that $\mathrm{P} 1$-derived proteoforms divert the binding of host antibodies away from regions in $\mathrm{P} 1$ required for adherence. We hypothesise that post-translational processing events release a proportion of P1-derived proteoforms into the extracellular milieu, a process that may represent an immune decoy mechanism that seeks to bind and direct host antibodies away from M. pneumoniae. A similar scenario has been hypothesized for Protein M of Mycoplasma genitalium; a close relative of M. pneumoniae ${ }^{79}$. 
Our affinity studies suggest that the different proteoforms retain the ability to bind to different host proteins, glycosaminoglycans and sialoglyconjugates. RP15 was observed to bind immobilised A549 cells in microtitre plate assays (Fig. 4). This was surprising as no adherence regions have been previously identified within RP15. Anti-RP15 antibodies were reported to be unable to inhibit M. pneumoniae adherence to primary human bronchial epithelial (HBEC) cells, human fetal lung fibroblasts (MRC-5), and human cervical carcinoma cells (HeLa) ${ }^{55}$ suggesting that RP15 may bind to specific receptors only present on the A549 cell surface. We were unable to determine binding activity to A549 cells for P1-30 or P1-15 (Fig. 4) because anti-RP-15 antibodies did not detect these peptides. To investigate the binding capabilities of the C-terminal peptide P1-15, it was bound to avidin agarose and incubated with A549 cell lysates. This strategy selectively recovered cytoskeletal proteins, vimentin, cytokeratin 7, cytokeratin 8, and cytokeratin 18 (Fig. S1) from P1-15-avidin agarose but not from avidin agarose control experiments. Although preliminary, these observations are worthy of further study. Cytokeratin 7 is found in epithelia of lungs and other tissues ${ }^{80}$, and has been shown to be involved in stabilising cytokeratin $18^{81}$. Both cytokeratin 8 and 18 are major structural proteins of epithelial cells ${ }^{82}$ and are found in the intermediate filaments of A549 cells $^{83}$. Cytokeratin 8 has been identified to reside on the cellular surface of carcinogenic keratinocyte cells (HaCat) ${ }^{84}$, carcinogenic mammary cells ${ }^{85}$, and carcinogenic hepatocytes ${ }^{86}$ suggesting they may be surface accessible on many cells. Cytokeratin 8 and 18 are co-expressed and frequently found associated together ${ }^{87,88}$. Vimentin forms filaments and is primarily expressed when epithelial cells transition into mesenchymal cells and function to induce changes in cell shape, motility and adhesin during this transition ${ }^{89,90}$. Vimentin has also been observed to be secreted to the extracellular matrix and on the surface of activated macrophages ${ }^{91}$. Cytokeratin 8 , 18 , and vimentin are suggested to be targeted by different pathogens after successfully invading host cells ${ }^{84,92-95}$ or after inducing cytoskeletal rearrangement ${ }^{96-100}$. Pathogenic bacteria are known to interact with these cytoskeletal proteins during infection ${ }^{95,101,102}$. Although mycoplasma have long been considered to be cell surface-associated parasitic bacteria, this dogma has been challenged with numerous reports citing phylogenetically-divergent mycoplasmas residing within eukaryote cells and possessing the molecular machinery for selective uptake into, survival within, and release from phagosomes ${ }^{103-109}$.

We recently showed that Mpn142, a member of the same operon that houses the P1 gene (mpn141), and the surface accessible moonlighting adhesin, elongation factor Tu (Ef-Tu), are cleaved extensively ${ }^{12,28}$. Post-translational processing of adhesins has been well characterised in M. hyopneumoniae where cleavage fragments have been shown to adhere to porcine cilia, porcine kidney epithelial cells, and a range of host molecules such as the glycosaminoglycan mimic heparin ${ }^{59-62,64,72,74,110-115}$, plasminogen ${ }^{60,112-114}$, actin ${ }^{116}$, and fibronec$\operatorname{tin}^{59,72,112-114}$. Processing of adhesin molecules is not confined to M. hyopneumoniae but has been described in Mycoplasma gallisepticum ${ }^{117}$, Mycoplasma fermentans ${ }^{118-120}$, M. genitalium $^{121}$, and Spiroplasma citri ${ }^{122}$. Here we show that major adhesion molecules in M. pneumoniae, a phylogenetically distinct human pathogen, are processed $^{12,28}$. All these studies suggest that the processing of surface accessible proteins is widespread in Mollicutes. It is notable that all the P1 fragments that were recovered during heparin affinity chromatography contained putative glycosaminoglycan binding motifs except an $\mathrm{N}$-terminal and a central fragment (Fig. 1, fragments 14 and 16). These motifs consist of clustered, positively charged amino acids that have been shown to have a role in binding to glycosaminoglycans $s^{69,72}$, actin ${ }^{123}$, and plasminogen ${ }^{123}$. Heparin mimics the glycosaminoglycans found in the extracellular matrix and on the surface of host cells ${ }^{124}$. M. hyopneumoniae, and M. gallisepticum have been shown to bind heparin to aid in host adherence ${ }^{110,125}$. Pathogens such as Staphylococcus and Neisseria spp., Helicobacter pylori, and Streptococcus pyogenes are able to recruit heparin to the bacterial cell surface and employ bound heparin to bind other host molecules ${ }^{126}$. Finally, heparin has also been implicated in biofilm formation by increasing cell-cell interactions in the Gram-positive pathogens, S. aureus ${ }^{127}$ and Lactobacillus rhamnosus ${ }^{128}$. M. pneumoniae forms large, complex biofilms on abiotic surfaces ${ }^{34}$. Heparin affinity chromatography of M. pneumoniae has been performed previously ${ }^{129}$ identifying only nine proteins, none of which was P1. Recently, we showed that Ef-Tu in M. pneumoniae displays a strong affinity to heparin ${ }^{12}$. Collectively, our studies suggest that the ability to bind heparin is a universal strategy in microbial pathogenesis.

In several instances, we observed multiple cleavage sites within P1 that clustered within a defined region of P1. For example, 18 cleavage sites clustered between amino acids 1343-1361 in the C-terminus of P1 (Table 1). Sequential cleavage patterns similar to this was also reported in $\mathrm{Mpn} 142^{28}$ and in Mhp493, a paralog of the major adhesin P97 (Mhp183) in M. hyopneumoniae ${ }^{74}$. Surfaceome studies of M. pneumoniae (data not shown) revealed the presence of surface accessible aminopeptidases that may target a neo- $\mathrm{N}$-terminal cleavage event and sequentially clip amino acids subsequent to the initial cleavage event. The function of these clipping events remains unknown but could be a mechanism to alter function and localisation of cleavage fragments, or represent a mechanism to recycle amino acids ${ }^{74}$. Cleavage site 14 in P1 (Fig. 1) occurs within a large predicted disordered region (amino acid range 1187-1382). The inherent flexibility of disordered regions make them accessible to protease activity $^{130}$. Many major cleavage events identified in M. hyopneumoniae adhesin molecules reside with large disordered regions ${ }^{60-62,74,114,115}$.

The C-terminus of the $\mathrm{P} 1$ tail is homologous to the C-terminus of Mpn142 and the C-terminal 15 amino acids of P1 ( ${ }^{1613}$ PGAPKPPVQPPKKPA ${ }^{1627}$ ) has $73.3 \%$ sequence identity with the same region in Mpn 142 . Almost half of this sequence consists of proline residues while lysine is also heavily represented in this region. Proline-rich regions in proteins have been implicated in protein:protein interactions $s^{131-133}$ and it has been suggested that proline residues could anchor the C-terminus of P1 in the cell membrane ${ }^{49}$. Lysine-rich regions are associated with binding plasminogen ${ }^{60,64,123,134,135}$, heparin ${ }^{59,61,69,72,115,136}$, actin $^{116,123}$, and DNA ${ }^{75,137}$. While P1-15 and P1-30 bound plasminogen in a dose-responsive manner, it was notable that RP-15 bound it more strongly. RP-15 also bound fibronectin and fibrinogen more strongly than P1-30 (Fig. 3). These data suggest that extra binding sites for these host molecules are located upstream of the C-terminal 30 amino acids of P1. Previous work suggests that sialic acid is the dominant host receptor for the P1 adhesin ${ }^{18-21}$. Consistent with these earlier studies the P1 tail has a strong affinity to the sialic acid rich protein, fetuin. Our data indicates that the mature P1 proteoform and a 
further nine smaller proteoforms of P1 bind fetuin. The ability to bind fetuin has been linked with biofilm formation in M. pneumoniae ${ }^{34}$.

\section{Conclusion}

In summary, this study reports that the P1 adhesin is subject to extensive post-translational processing forming twenty-two proteoforms from seventeen cleavage sites. Each of the proteoforms retain the ability to bind to host molecules or their structural mimics and are surface accessible. Processing has been described in M. hyopneumoniae, M. gallisepticum, and S. citri and is likely to be a widespread mechanism to generate surface protein diversity and promote protein:protein interactions. Specifically we show that the C-terminus of P1 plays a role in adhering to a range of host molecules including cytoskeletal proteins. This study expands on our knowledge of the role that the $\mathrm{P} 1$ adhesin plays in interactions between M. pneumoniae and host cells.

\section{Data availability}

Data for this study is available on request from the corresponding author.

Received: 17 January 2019; Accepted: 20 March 2020;

Published online: 14 April 2020

\section{References}

1. Krause, D. C. \& Balish, M. F. Structure, function, and assembly of the terminal organelle of Mycoplasma pneumoniae. FEMS Microbiol Lett 198, 1-7 (2001).

2. Baseman, J. B., Cole, R. M., Krause, D. C. \& Leith, D. K. Molecular basis for cytadsorption of Mycoplasma pneumoniae. J Bacteriol 151, 1514-1522 (1982).

3. Feldner, J., Gobel, U. \& Bredt, W. Mycoplasma pneumoniae adhesin localized to tip structure by monoclonal antibody. Nature 298, 765-767 (1982).

4. Krause, D. C. Mycoplasma pneumoniae cytadherence: unravelling the tie that binds. Mol Microbiol 20, 247-253 (1996).

5. Seto, S., Layh-Schmitt, G., Kenri, T. \& Miyata, M. Visualization of the attachment organelle and cytadherence proteins of Mycoplasma pneumoniae by immunofluorescence microscopy. J Bacteriol 183, 1621-1630, https://doi.org/10.1128/JB.183.5.16211630.2001 (2001).

6. Seto, S. \& Miyata, M. Attachment organelle formation represented by localization of cytadherence proteins and formation of the electron-dense core in wild-type and mutant strains of Mycoplasma pneumoniae. J Bacteriol 185, 1082-1091 (2003).

7. Nakane, D., Kenri, T., Matsuo, L. \& Miyata, M. Systematic Structural Analyses of Attachment Organelle in Mycoplasma pneumoniae. PLoS Pathog 11, e1005299, https://doi.org/10.1371/journal.ppat.1005299 (2015).

8. Baseman, J. B. et al. Identification of a 32-kilodalton protein of Mycoplasma pneumoniae associated with hemadsorption. Isr J Med Sci 23, 474-479 (1987).

9. Dallo, S. F., Kannan, T. R., Blaylock, M. W. \& Baseman, J. B. Elongation factor Tu and E1 beta subunit of pyruvate dehydrogenase complex act as fibronectin binding proteins in Mycoplasma pneumoniae. Mol Microbiol 46, 1041-1051 (2002).

10. Gründel, A., Jacobs, E. \& Dumke, R. Interactions of surface-displayed glycolytic enzymes of Mycoplasma pneumoniae with components of the human extracellular matrix. Int J Med Microbiol, https://doi.org/10.1016/j.ijmm.2016.09.001 (2016).

11. Hagemann, L., Gründel, A., Jacobs, E. \& Dumke, R. The surface-displayed chaperones GroEL and DnaK of Mycoplasma pneumoniae interact with human plasminogen and components of the extracellular matrix. Pathog Dis, https://doi.org/10.1093/ femspd/ftx017 (2017).

12. Widjaja, M. et al. Elongation factor Tu is a multifunctional and processed moonlighting protein. Sci Rep 7, 11227, https://doi. org/10.1038/s41598-017-10644-z (2017).

13. Grimmer, J. \& Dumke, R. Organization of multi-binding to host proteins: The glyceraldehyde-3-phosphate dehydrogenase (GAPDH) of Mycoplasma pneumoniae. Microbiol Res 218, 22-31, https://doi.org/10.1016/j.micres.2018.09.006 (2019).

14. Dumke, R., Hausner, M. \& Jacobs, E. Role of Mycoplasma pneumoniae glyceraldehyde-3-phosphate dehydrogenase (GAPDH) in mediating interactions with the human extracellular matrix. Microbiology 157, 2328-2338, https://doi.org/10.1099/mic.0.0482980 (2011).

15. Thomas, C., Jacobs, E. \& Dumke, R. Characterization of pyruvate dehydrogenase subunit B and enolase as plasminogen-binding proteins in Mycoplasma pneumoniae. Microbiology 159, 352-365, https://doi.org/10.1099/mic.0.061184-0 (2013).

16. Gründel, A., Friedrich, K., Pfeiffer, M., Jacobs, E. \& Dumke, R. Subunits of the Pyruvate Dehydrogenase Cluster of Mycoplasma pneumoniae Are Surface-Displayed Proteins that Bind and Activate Human Plasminogen. PLoS One 10, e0126600, https://doi. org/10.1371/journal.pone.0126600 (2015).

17. Gründel, A., Pfeiffer, M., Jacobs, E. \& Dumke, R. Network of Surface-Displayed Glycolytic Enzymes in Mycoplasma pneumoniae and Their Interactions with Human Plasminogen. Infect Immun 84, 666-676, https://doi.org/10.1128/IAI.01071-15 (2016).

18. Kahane, I., Banai, M., Razin, S. \& Feldner, J. Attachment of mycoplasmas to host cell membranes. Rev Infect Dis 4(Suppl), S185-192 (1982).

19. Loomes, L. M. et al. Erythrocyte receptors for Mycoplasma pneumoniae are sialylated oligosaccharides of Ii antigen type. Nature 307, 560-563 (1984)

20. Loomes, L. M., Uemura, K. \& Feizi, T. Interaction of Mycoplasma pneumoniae with erythrocyte glycolipids of I and i antigen types. Infect Immun 47, 15-20 (1985).

21. Roberts, D. D., Olson, L. D., Barile, M. F., Ginsburg, V. \& Krivan, H. C. Sialic acid-dependent adhesion of Mycoplasma pneumoniae to purified glycoproteins. J Biol Chem 264, 9289-9293 (1989).

22. Inamine, J. M., Loechel, S. \& Hu, P. C. Analysis of the nucleotide sequence of the P1 operon of Mycoplasma pneumoniae. Gene 73, 175-183 (1988).

23. Waldo, R. H. III. \& Krause, D. C. Synthesis, stability, and function of cytadhesin P1 and accessory protein B/C complex of Mycoplasma pneumoniae. J Bacteriol 188, 569-575, https://doi.org/10.1128/JB.188.2.569-575.2006 (2006).

24. Aravind, L. \& Koonin, E. V. A novel family of predicted phosphoesterases includes Drosophila prune protein and bacterial RecJ exonuclease. Trends Biochem Sci 23, 17-19 (1998).

25. Postic, G., Danchin, A. \& Mechold, U. Characterization of NrnA homologs from Mycobacterium tuberculosis and Mycoplasma pneumoniae. RNA 18, 155-165, https://doi.org/10.1261/rna.029132.111 (2012).

26. Sperker, B., Hu, P. \& Herrmann, R. Identification of gene products of the P1 operon of Mycoplasma pneumoniae. Mol Microbiol 5, 299-306 (1991).

27. Layh-Schmitt, G. \& Herrmann, R. Localization and biochemical characterization of the ORF6 gene product of the Mycoplasma pneumoniae P1 operon. Infect Immun 60, 2906-2913 (1992). 
28. Widjaja, M., Berry, I. J., Pont, E. J., Padula, M. P. \& Djordjevic, S. P. P40 and P90 from Mpn142 are Targets of Multiple Processing Events on the Surface of Mycoplasma pneumoniae. Proteomes 3, 512-537, https://doi.org/10.3390/proteomes3040512 (2015).

29. Inamine, J. M. et al. Nucleotide sequence of the P1 attachment-protein gene of Mycoplasma pneumoniae. Gene 64, 217-229 (1988).

30. Layh-Schmitt, G. \& Herrmann, R. Spatial arrangement of gene products of the P1 operon in the membrane of Mycoplasma pneumoniae. Infect Immun 62, 974-979 (1994).

31. Franzoso, G., Hu, P. C., Meloni, G. A. \& Barile, M. F. The immunodominant 90-kilodalton protein is localized on the terminal tip structure of Mycoplasma pneumoniae. Infect Immun 61, 1523-1530 (1993).

32. Nakane, D., Adan-Kubo, J., Kenri, T. \& Miyata, M. Isolation and characterization of P1 adhesin, a leg protein of the gliding bacterium Mycoplasma pneumoniae. J Bacteriol 193, 715-722, https://doi.org/10.1128/JB.00796-10 (2011).

33. Layh-Schmitt, G., Podtelejnikov, A. \& Mann, M. Proteins complexed to the P1 adhesin of Mycoplasma pneumoniae. Microbiology 146(Pt 3), 741-747 (2000)

34. Kornspan, J. D., Tarshis, M. \& Rottem, S. Adhesion and biofilm formation of Mycoplasma pneumoniae on an abiotic surface. Arch Microbiol 193, 833-836, https://doi.org/10.1007/s00203-011-0749-y (2011).

35. Hu, P. C. et al. Mycoplasma pneumoniae infection: role of a surface protein in the attachment organelle. Science 216, 313-315 (1982).

36. Razin, S. \& Jacobs, E. Mycoplasma adhesion. J Gen Microbiol 138, 407-422, https://doi.org/10.1099/00221287-138-3-407 (1992).

37. Svenstrup, H. F., Nielsen, P. K., Drasbek, M., Birkelund, S. \& Christiansen, G. Adhesion and inhibition assay of Mycoplasma genitalium and M. pneumoniae by immunofluorescence microscopy. J Med Microbiol 51, 361-373, https://doi.org/10.1099/00221317-51-5-361 (2002).

38. Seto, S., Kenri, T., Tomiyama, T. \& Miyata, M. Involvement of P1 adhesin in gliding motility of Mycoplasma pneumoniae as revealed by the inhibitory effects of antibody under optimized gliding conditions. J Bacteriol 187, 1875-1877, https://doi. org/10.1128/JB.187.5.1875-1877.2005 (2005).

39. Hu, P. C., Collier, A. M. \& Baseman, J. B. Surface parasitism by Mycoplasma pneumoniae of respiratory epithelium. J Exp Med 145, 1328-1343 (1977).

40. Kahane, I., Tucker, S., Leith, D. K., Morrison-Plummer, J. \& Baseman, J. B. Detection of the major adhesin P1 in triton shells of virulent Mycoplasma pneumoniae. Infect Immun 50, 944-946 (1985).

41. Morrison-Plummer, J., Leith, D. K. \& Baseman, J. B. Biological effects of anti-lipid and anti-protein monoclonal antibodies on Mycoplasma pneumoniae. Infect Immun 53, 398-403 (1986).

42. Krause, D. C. \& Balish, M. F. Cellular engineering in a minimal microbe: structure and assembly of the terminal organelle of Mycoplasma pneumoniae. Mol Microbiol 51, 917-924 (2004).

43. Layh-Schmitt, G. \& Harkenthal, M. The 40- and 90-kDa membrane proteins (ORF6 gene product) of Mycoplasma pneumoniae are responsible for the tip structure formation and P1 (adhesin) association with the Triton shell. FEMS Microbiol Lett 174, 143-149 (1999).

44. Waldo, R. H. III., Jordan, J. L. \& Krause, D. C. Identification and complementation of a mutation associated with loss of Mycoplasma pneumoniae virulence-specific proteins B and C. J Bacteriol 187, 747-751, https://doi.org/10.1128/JB.187.2.747751.2005 (2005)

45. Hahn, T. W., Willby, M. J. \& Krause, D. C. HMW1 is required for cytadhesin P1 trafficking to the attachment organelle in Mycoplasma pneumoniae. J Bacteriol 180, 1270-1276 (1998).

46. Cloward, J. M. \& Krause, D. C. Loss of co-chaperone TopI impacts adhesin P1 presentation and terminal organelle maturation in Mycoplasma pneumoniae. Mol Microbiol 81, 528-539, https://doi.org/10.1111/j.1365-2958.2011.07712.x (2011).

47. Hirschberg, L., Holme, T. \& Krook, A. Human antibody response to the major adhesin of Mycoplasma pneumoniae: increase in titers against synthetic peptides in patients with pneumonia. APMIS 99, 515-520 (1991).

48. Tuuminen, T., Suni, J., Kleemola, M. \& Jacobs, E. Improved sensitivity and specificity of enzyme immunoassays with P1-adhesin enriched antigen to detect acute Mycoplasma pneumoniae infection. J Microbiol Methods 44, 27-37 (2001).

49. Dallo, S. F., Su, C. J., Horton, J. R. \& Baseman, J. B. Identification of P1 gene domain containing epitope(s) mediating Mycoplasma pneumoniae cytoadherence. J Exp Med 167, 718-723 (1988).

50. Gerstenecker, B. \& Jacobs, E. Topological mapping of the P1-adhesin of Mycoplasma pneumoniae with adherence-inhibiting monoclonal antibodies. J Gen Microbiol 136, 471-476, https://doi.org/10.1099/00221287-136-3-471 (1990).

51. Jacobs, E., Bartl, A., Oberle, K. \& Schiltz, E. Molecular mimicry by Mycoplasma pneumoniae to evade the induction of adherence inhibiting antibodies. J Med Microbiol 43, 422-429, https://doi.org/10.1099/00222615-43-6-422 (1995).

52. Chaudhry, R., Nisar, N., Hora, B., Chirasani, S. R. \& Malhotra, P. Expression and immunological characterization of the carboxyterminal region of the P1 adhesin protein of Mycoplasma pneumoniae. J Clin Microbiol 43, 321-325, https://doi.org/10.1128/ JCM.43.1.321-325.2005 (2005)

53. Drasbek, M., Christiansen, G., Drasbek, K. R., Holm, A. \& Birkelund, S. Interaction between the P1 protein of Mycoplasma pneumoniae and receptors on HEp-2 cells. Microbiology 153, 3791-3799, https://doi.org/10.1099/mic.0.2007/010736-0 (2007).

54. Beghetto, E., De Paolis, F., Montagnani, F., Cellesi, C. \& Gargano, N. Discovery of new Mycoplasma pneumoniae antigens by use of a whole-genome lambda display library. Microbes Infect 11, 66-73, https://doi.org/10.1016/j.micinf.2008.10.004 (2009).

55. Schurwanz, N., Jacobs, E. \& Dumke, R. Strategy to create chimeric proteins derived from functional adhesin regions of Mycoplasma pneumoniae for vaccine development. Infect Immun 77, 5007-5015, https://doi.org/10.1128/IAI.00268-09 (2009).

56. Hausner, M., Schamberger, A., Naumann, W., Jacobs, E. \& Dumke, R. Development of protective anti-Mycoplasma pneumoniae antibodies after immunization of guinea pigs with the combination of a P1-P30 chimeric recombinant protein and chitosan. Microb Pathog 64, 23-32, https://doi.org/10.1016/j.micpath.2013.07.004 (2013).

57. Berry, I. J. et al. N-terminomics identifies widespread endoproteolysis and novel methionine excision in a genome-reduced bacterial pathogen. Sci Rep 7, 11063, https://doi.org/10.1038/s41598-017-11296-9 (2017).

58. Hayflick, L. Tissue cultures and mycoplasmas. Tex Rep Biol Med 23(Suppl 1), 285+ (1965).

59. Deutscher, A. T. et al. Repeat regions R1 and R2 in the P97 paralogue Mhp271 of Mycoplasma hyopneumoniae bind heparin, fibronectin and porcine cilia. Mol Microbiol 78, 444-458, https://doi.org/10.1111/j.1365-2958.2010.07345.x (2010).

60. Bogema, D. R. et al. Characterization of cleavage events in the multifunctional cilium adhesin Mhp684 (P146) reveals a mechanism by which Mycoplasma hyopneumoniae regulates surface topography. MBio 3, https://doi.org/10.1128/mBio.00282-11 (2012).

61. Raymond, B. B. et al. P159 from Mycoplasma hyopneumoniae binds porcine cilia and heparin and is cleaved in a manner akin to ectodomain shedding. J Proteome Res 12, 5891-5903, https://doi.org/10.1021/pr400903s (2013).

62. Bogema, D. R. et al. Sequence TTKF downward arrow QE defines the site of proteolytic cleavage in Mhp683 protein, a novel glycosaminoglycan and cilium adhesin of Mycoplasma hyopneumoniae. J Biol Chem 286, 41217-41229, https://doi.org/10.1074/ jbc.M111.226084 (2011).

63. Webb, A. Systems Biology Mascot Server: Databases (MSPnr100), http://www.wehi.edu.au/people/andrew-webb/1295/andrewwebb-resources (2015).

64. Tacchi, J. L. et al. Post-translational processing targets functionally diverse proteins in Mycoplasma hyopneumoniae. Open Biol 6, 150210, https://doi.org/10.1098/rsob.150210 (2016).

65. Wilkins, M. R. et al. Protein identification and analysis tools in the ExPASy server. Methods Mol Biol 112, 531-552 (1999).

66. Hofmann, K. \& TMbase, S. W. - A database of membrane spanning proteins segments. Biol. Chem. 374, 166 (1993). 
67. Peng, K., Radivojac, P., Vucetic, S., Dunker, A. K. \& Obradovic, Z. Length-dependent prediction of protein intrinsic disorder. BMC Bioinformatics 7, 208, https://doi.org/10.1186/1471-2105-7-208 (2006).

68. de Castro, E. et al. ScanProsite: detection of PROSITE signature matches and ProRule-associated functional and structural residues in proteins. Nucleic Acids Res 34, W362-365, https://doi.org/10.1093/nar/gkl124 (2006).

69. Cardin, A. D. \& Weintraub, H. J. Molecular modeling of protein-glycosaminoglycan interactions. Arteriosclerosis 9, 21-32 (1989).

70. Klimstra, W. B., Heidner, H. W. \& Johnston, R. E. The furin protease cleavage recognition sequence of Sindbis virus PE2 can mediate virion attachment to cell surface heparan sulfate. J Virol 73, 6299-6306 (1999).

71. Kyhse-Andersen, J. Electroblotting of multiple gels: a simple apparatus without buffer tank for rapid transfer of proteins from polyacrylamide to nitrocellulose. J Biochem Biophys Methods 10, 203-209 (1984).

72. Raymond, B. B. et al. Proteolytic processing of the cilium adhesin MHJ_0194 (P123J) in Mycoplasma hyopneumoniae generates a functionally diverse array of cleavage fragments that bind multiple host molecules. Cell Microbiol 17, 425-444, https://doi. org/10.1111/cmi.12377 (2015).

73. Aparicio, D. et al. Mycoplasma genitalium adhesin P110 binds sialic-acid human receptors. Nat Commun 9, 4471, https://doi. org/10.1038/s41467-018-06963-y (2018).

74. Tacchi, J. L. et al. Cilium adhesin P216 (MHJ_0493) is a target of ectodomain shedding and aminopeptidase activity on the surface of Mycoplasma hyopneumoniae. J Proteome Res 13, 2920-2930, https://doi.org/10.1021/pr500087c (2014).

75. Jarocki, V. M. et al. MHJ_0461 is a multifunctional leucine aminopeptidase on the surface of Mycoplasma hyopneumoniae. Open Biol 5, 140175, https://doi.org/10.1098/rsob.140175 (2015).

76. Hahm, K. S. et al. Limited proteolysis selectively destroys epitopes on apolipoprotein B in low density lipoproteins. J Lipid Res 24, $877-885$ (1983)

77. Mayne, R. et al. Monoclonal antibody to the aminotelopeptide of type II collagen: loss of the epitope after stromelysin digestion. Connect Tissue Res 31, 11-21, https://doi.org/10.3109/03008209409005631 (1994).

78. Ossendorp, F. et al. A single residue exchange within a viral CTL epitope alters proteasome-mediated degradation resulting in lack of antigen presentation. Immunity 5, 115-124, https://doi.org/10.1016/s1074-7613(00)80488-4 (1996).

79. Grover, R. K. et al. A structurally distinct human mycoplasma protein that generically blocks antigen-antibody union. Science 343, 656-661, https://doi.org/10.1126/science.1246135 (2014).

80. van Niekerk, C. C., Jap, P. H., Ramaekers, F. C., van de Molengraft, F. \& Poels, L. G. Immunohistochemical demonstration of keratin 7 in routinely fixed paraffin-embedded human tissues. J Pathol 165, 145-152, https://doi.org/10.1002/path.1711650210 (1991).

81. Sandilands, A. et al. Generation and characterisation of keratin 7 (K7) knockout mice. PLoS One 8, e64404, https://doi.org/10.1371/ journal.pone.0064404 (2013).

82. Owens, D. W. \& Lane, E. B. The quest for the function of simple epithelial keratins. Bioessays 25, 748-758, https://doi.org/10.1002/ bies.10316 (2003).

83. Dobashi, N. et al. Detection of anti-cytokeratin 8 antibody in the serum of patients with cryptogenic fibrosing alveolitis and pulmonary fibrosis associated with collagen vascular disorders. Thorax 53, 969-974 (1998)

84. Haim, M. et al. Cytokeratin 8 interacts with clumping factor B: a new possible virulence factor target. Microbiology 156, 3710-3721, https://doi.org/10.1099/mic.0.034413-0 (2010).

85. Godfroid, E., Geuskens, M., Dupressoir, T., Parent, I. \& Szpirer, C. Cytokeratins are exposed on the outer surface of established human mammary carcinoma cells. J Cell Sci 99(Pt 3), 595-607 (1991).

86. Hembrough, T. A., Vasudevan, J., Allietta, M. M., Glass, W. F. 2nd \& Gonias, S. L. A cytokeratin 8-like protein with plasminogenbinding activity is present on the external surfaces of hepatocytes, HepG2 cells and breast carcinoma cell lines. J Cell Sci 108(Pt 3), 1071-1082 (1995).

87. Lu, X. \& Lane, E. B. Retrovirus-mediated transgenic keratin expression in cultured fibroblasts: specific domain functions in keratin stabilization and filament formation. Cell 62, 681-696 (1990).

88. Moll, R., Franke, W. W., Schiller, D. L., Geiger, B. \& Krepler, R. The catalog of human cytokeratins: patterns of expression in normal epithelia, tumors and cultured cells. Cell 31, 11-24 (1982).

89. Mendez, M. G., Kojima, S. \& Goldman, R. D. Vimentin induces changes in cell shape, motility, and adhesion during the epithelial to mesenchymal transition. FASEB J 24, 1838-1851, https://doi.org/10.1096/fi.09-151639 (2010).

90. Franke, W. W., Schiller, D. L., Hatzfeld, M. \& Winter, S. Protein complexes of intermediate-sized filaments: melting of cytokeratin complexes in urea reveals different polypeptide separation characteristics. Proc Natl Acad Sci USA 80, 7113-7117 (1983).

91. Mor-Vaknin, N., Punturieri, A., Sitwala, K. \& Markovitz, D. M. Vimentin is secreted by activated macrophages. Nat Cell Biol 5, 59-63, https://doi.org/10.1038/ncb898 (2003).

92. Tamura, G. S. \& Nittayajarn, A. Group B streptococci and other gram-positive cocci bind to cytokeratin 8. Infect Immun 68 $2129-2134(2000)$

93. Scherer, C. A., Cooper, E. \& Miller, S. I. The Salmonella type III secretion translocon protein SspC is inserted into the epithelial cell plasma membrane upon infection. Mol Microbiol 37, 1133-1145 (2000)

94. Carlson, S. A., Omary, M. B. \& Jones, B. D. Identification of cytokeratins as accessory mediators of Salmonella entry into eukaryotic cells. Life Sci 70, 1415-1426 (2002).

95. Mak, T. N. et al. Propionibacterium acnes host cell tropism contributes to vimentin-mediated invasion and induction of inflammation. Cell Microbiol 14, 1720-1733, https://doi.org/10.1111/j.1462-5822.2012.01833.x (2012).

96. Batchelor, M. et al. Involvement of the intermediate filament protein cytokeratin-18 in actin pedestal formation during EPEC infection. EMBO Rep 5, 104-110, https://doi.org/10.1038/sj.embor.7400038 (2004).

97. Viswanathan, V. K. et al. Cytokeratin 18 interacts with the enteropathogenic Escherichia coli secreted protein $\mathrm{F}(\mathrm{EspF})$ and is redistributed after infection. Cell Microbiol 6, 987-997, https://doi.org/10.1111/j.1462-5822.2004.00416.x (2004).

98. Icenogle, L. M. et al. Molecular and biological characterization of Streptococcal SpyA-mediated ADP-ribosylation of intermediate filament protein vimentin. J Biol Chem 287, 21481-21491, https://doi.org/10.1074/jbc.M112.370791 (2012).

99. Murli, S., Watson, R. O. \& Galan, J. E. Role of tyrosine kinases and the tyrosine phosphatase SptP in the interaction of Salmonella with host cells. Cell Microbiol 3, 795-810 (2001).

100. Guignot, J. \& Servin, A. L. Maintenance of the Salmonella-containing vacuole in the juxtanuclear area: a role for intermediate filaments. Microb Pathog 45, 415-422, https://doi.org/10.1016/j.micpath.2008.09.007 (2008).

101. Saberi, S. et al. A potential association between Helicobacter pylori CagA EPIYA and multimerization motifs with cytokeratin 18 cleavage rate during early apoptosis. Helicobacter 17, 350-357, https://doi.org/10.1111/j.1523-5378.2012.00954.x (2012).

102. Kumar, Y. \& Valdivia, R. H. Actin and intermediate filaments stabilize the Chlamydia trachomatis vacuole by forming dynamic structural scaffolds. Cell Host Microbe 4, 159-169, https://doi.org/10.1016/j.chom.2008.05.018 (2008).

103. Yavlovich, A., Tarshis, M. \& Rottem, S. Internalization and intracellular survival of Mycoplasma pneumoniae by non-phagocytic cells. FEMS Microbiol Lett 233, 241-246, https://doi.org/10.1016/j.femsle.2004.02.016 (2004).

104. Tsiodras, S., Kelesidis, I., Kelesidis, T., Stamboulis, E. \& Giamarellou, H. Central nervous system manifestations of Mycoplasma pneumoniae infections. J Infect 51, 343-354, https://doi.org/10.1016/j.jinf.2005.07.005 (2005).

105. Burki, S. et al. Invasion and persistence of Mycoplasma bovis in embryonic calf turbinate cells. Vet Res 46, 53, https://doi. org/10.1186/s13567-015-0194-z (2015)

106. Burki, S., Frey, J. \& Pilo, P. Virulence, persistence and dissemination of Mycoplasma bovis. Vet Microbiol 179, 15-22, https://doi. org/10.1016/j.vetmic.2015.02.024 (2015). 
107. Suleman, M. et al. Mycoplasma bovis isolates recovered from cattle and bison (Bison bison) show differential in vitro effects on PBMC proliferation, alveolar macrophage apoptosis and invasion of epithelial and immune cells. Vet Microbiol 186, 28-36, https:// doi.org/10.1016/j.vetmic.2016.02.016 (2016).

108. Josi, C. et al. Bovine Epithelial in vitro Infection Models for Mycoplasma bovis. Frontiers in cellular and infection microbiology 8 , 329, https://doi.org/10.3389/fcimb.2018.00329 (2018).

109. Raymond, B. B. A. et al. Mycoplasma hyopneumoniae resides intracellularly within porcine epithelial cells. Sci Rep 8, 17697, https://doi.org/10.1038/s41598-018-36054-3 (2018).

110. Burnett, T. A. et al. P159 is a proteolytically processed, surface adhesin of Mycoplasma hyopneumoniae: defined domains of P159 bind heparin and promote adherence to eukaryote cells. Mol Microbiol 60, 669-686, https://doi. org/10.1111/j.1365-2958.2006.05139.x (2006).

111. Wilton, J. et al. Mhp493 (P216) is a proteolytically processed, cilium and heparin binding protein of Mycoplasma hyopneumoniae. Mol Microbiol 71, 566-582, https://doi.org/10.1111/j.1365-2958.2008.06546.x (2009).

112. Seymour, L. M. et al. A processed multidomain mycoplasma hyopneumoniae adhesin binds fibronectin, plasminogen, and swine respiratory cilia. J Biol Chem 285, 33971-33978, https://doi.org/10.1074/jbc.M110.104463 (2010).

113. Seymour, L. M. et al. Mhp107 is a member of the multifunctional adhesin family of Mycoplasma hyopneumoniae. J Biol Chem 286, 10097-10104, https://doi.org/10.1074/jbc.M110.208140 (2011).

114. Seymour, L. M. et al. Mhp182 (P102) binds fibronectin and contributes to the recruitment of plasmin(ogen) to the Mycoplasma hyopneumoniae cell surface. Cell Microbiol 14, 81-94, https://doi.org/10.1111/j.1462-5822.2011.01702.x (2012).

115. Deutscher, A. T. et al. Mycoplasma hyopneumoniae Surface proteins Mhp385 and Mhp384 bind host cilia and glycosaminoglycans and are endoproteolytically processed by proteases that recognize different cleavage motifs. J Proteome Res 11, 1924-1936, https:// doi.org/10.1021/pr201115v (2012).

116. Raymond, B. B. A. et al. Extracellular Actin Is a Receptor for Mycoplasma hyopneumoniae. Frontiers in cellular and infection microbiology 8, 54, https://doi.org/10.3389/fcimb.2018.00054 (2018).

117. Szczepanek, S. M. et al. Identification of lipoprotein MslA as a neoteric virulence factor of Mycoplasma gallisepticum. Infect Immun 78, 3475-3483, https://doi.org/10.1128/IAI.00154-10 (2010).

118. Calcutt, M. J., Kim, M. F., Karpas, A. B., Muhlradt, P. F. \& Wise, K. S. Differential posttranslational processing confers intraspecies variation of a major surface lipoprotein and a macrophage-activating lipopeptide of Mycoplasma fermentans. Infect Immun 67, 760-771 (1999).

119. Davis, K. L. \& Wise, K. S. Site-specific proteolysis of the MALP-404 lipoprotein determines the release of a soluble selective lipoprotein-associated motif-containing fragment and alteration of the surface phenotype of Mycoplasma fermentans. Infect Immun 70, 1129-1135 (2002).

120. Muhlradt, P. F., Kiess, M., Meyer, H., Sussmuth, R. \& Jung, G. Isolation, structure elucidation, and synthesis of a macrophage stimulatory lipopeptide from Mycoplasma fermentans acting at picomolar concentration. J Exp Med 185, 1951-1958 (1997).

121. Shimizu, T., Kida, Y. \& Kuwano, K. A triacylated lipoprotein from Mycoplasma genitalium activates NF-kappaB through Toll-like receptor 1 (TLR1) and TLR2. Infect Immun 76, 3672-3678, https://doi.org/10.1128/IAI.00257-08 (2008).

122. Dubrana, M. P. et al. Proteolytic post-translational processing of adhesins in the plant pathogen Spiroplasma citri. J Mol Biol https://doi.org/10.1016/j.jmb.2017.05.004 (2017).

123. Boone, T. J. \& Tyrrell, G. J. Identification of the actin and plasminogen binding regions of group B streptococcal phosphoglycerate kinase. J Biol Chem 287, 29035-29044, https://doi.org/10.1074/jbc.M112.361261 (2012).

124. Kamhi, E., Joo, E. J., Dordick, J. S. \& Linhardt, R. J. Glycosaminoglycans in infectious disease. Biol Rev Camb Philos Soc 88, 928-943, https://doi.org/10.1111/brv.12034 (2013).

125. Jenkins, C., Geary, S. J., Gladd, M. \& Djordjevic, S. P. The Mycoplasma gallisepticum OsmC-like protein MG1142 resides on the cell surface and binds heparin. Microbiology 153, 1455-1463, https://doi.org/10.1099/mic.0.2006/004937-0 (2007).

126. Duensing, T. D., Wing, J. S. \& van Putten, J. P. Sulfated polysaccharide-directed recruitment of mammalian host proteins: a novel strategy in microbial pathogenesis. Infect Immun 67, 4463-4468 (1999).

127. Shanks, R. M. et al. Heparin stimulates Staphylococcus aureus biofilm formation. Infect Immun 73, 4596-4606, https://doi. org/10.1128/IAI.73.8.4596-4606.2005 (2005).

128. Chen, X. E., Ling, P., Duan, R. \& Zhang, T. Effects of heparosan and heparin on the adhesion and biofilm formation of several bacteria in vitro. Carbohydrate polymers 88, 1288-1292 (2012).

129. Ueberle, B., Frank, R. \& Herrmann, R. The proteome of the bacterium Mycoplasma pneumoniae: comparing predicted open reading frames to identified gene products. Proteomics 2, 754-764, 10.1002/1615-9861(200206)2:6<754::AIDPROT754>3.0.CO;2-2 (2002).

130. Uversky, V. N. \& Dunker, A. K. Understanding protein non-folding. Biochim Biophys Acta 1804, 1231-1264, https://doi. org/10.1016/j.bbapap.2010.01.017 (2010).

131. Boguslavsky, S. et al. Molecular characterization of the Mycoplasma gallisepticum pvpA gene which encodes a putative variable cytadhesin protein. Infect Immun 68, 3956-3964 (2000).

132. Williamson, M. P. The structure and function of proline-rich regions in proteins. Biochem J 297(Pt 2), 249-260 (1994).

133. Kay, B. K., Williamson, M. P. \& Sudol, M. The importance of being proline: the interaction of proline-rich motifs in signaling proteins with their cognate domains. FASEB J 14, 231-241 (2000).

134. Cork, A. J. et al. Defining the structural basis of human plasminogen binding by streptococcal surface enolase. J Biol Chem 284, 17129-17137, https://doi.org/10.1074/jbc.M109.004317 (2009).

135. Raymond, B. B. \& Djordjevic, S. Exploitation of plasmin(ogen) by bacterial pathogens of veterinary significance. Vet Microbiol 178, 1-13, https://doi.org/10.1016/j.vetmic.2015.04.008 (2015).

136. Robinson, M. W. et al. MHJ_0125 is an M42 glutamyl aminopeptidase that moonlights as a multifunctional adhesin on the surface of Mycoplasma hyopneumoniae. Open Biol 3, 130017, https://doi.org/10.1098/rsob.130017 (2013).

137. Lee, A. Y., Hsu, C. H. \& Wu, S. H. Functional domains of Brevibacillus thermoruber lon protease for oligomerization and DNA binding: role of N-terminal and sensor and substrate discrimination domains. J Biol Chem 279, 34903-34912, https://doi. org/10.1074/jbc.M403562200 (2004).

\section{Acknowledgements}

This research is supported by an Australian Government Research Training Program Scholarship provided to I.J.B. The authors would like to thank Mark Raftery and the Bioanalytical Mass Spectrometry Facility (BMSF) for access to the Sciex 5600 and Thermo Scientific Q Exactive ${ }^{\mathrm{TM}}$ Plus mass spectrometers purchased with the ARC grant LE130100096 entitled 'Advanced high resolution mass spectrometer for collaborative proteomic and lipidomics research'. The authors would like to thank both the University of Technology Sydney and the Technische Universität Dresden for funding this research. 


\section{Author contributions}

M.W. acquired and analysed the data except those listed for I.J.B., V.M.J. and R.D. Dimethyl labelling experiments was performed by I.J.B. Results from dimethyl labelling experiments was analysed by both M.W. and I.J.B. The experiments investigating the binding of the P1 C-terminus to human proteins and A549 human lung cells were conducted and analysed by R.D. Microscale thermophoresis of the scrambled P1 peptide was performed and data analysed by V.M.J. Acquisition of mass spectrometry data was performed by M.P.P. who also assisted with mass spectrometry data interpretation. R.D. created the figures for microtitre plate binding assays and all other figures were created by M.W. Both M.W. and S.P.D. wrote the manuscript. S.P.D. initiated the study. Both S.P.D. and R.D. secured funding for this study. The manuscript was reviewed and approved by all authors before submission.

\section{Competing interests}

The authors declare no competing interests.

\section{Additional information}

Supplementary information is available for this paper at https://doi.org/10.1038/s41598-020-63136-y.

Correspondence and requests for materials should be addressed to S.P.D.

Reprints and permissions information is available at www.nature.com/reprints.

Publisher's note Springer Nature remains neutral with regard to jurisdictional claims in published maps and institutional affiliations.

(c) (i) Open Access This article is licensed under a Creative Commons Attribution 4.0 International

License, which permits use, sharing, adaptation, distribution and reproduction in any medium or format, as long as you give appropriate credit to the original author(s) and the source, provide a link to the Creative Commons license, and indicate if changes were made. The images or other third party material in this article are included in the article's Creative Commons license, unless indicated otherwise in a credit line to the material. If material is not included in the article's Creative Commons license and your intended use is not permitted by statutory regulation or exceeds the permitted use, you will need to obtain permission directly from the copyright holder. To view a copy of this license, visit http://creativecommons.org/licenses/by/4.0/.

(C) The Author(s) 2020 